\title{
Mafic-felsic magma interaction at Satsuma-Iwojima volcano, Japan: Evidence from mafic inclusions in rhyolites
}

\author{
Genji Saito $^{1}$, James A. Stimac ${ }^{2}$, Yoshihisa Kawanabe ${ }^{1}$, and Fraser Goff ${ }^{3}$ \\ ${ }^{1}$ Geological Survey of Japan, AIST, Central 7, Higashi 1-1-1, Tsukuba, Ibaraki 305-8567, Japan \\ ${ }^{2}$ Philippine Geothermal, Inc., 12th Fl. Citibank Tower, 8741 Paseo de Roxas, Makati, Philippines \\ ${ }^{3}$ EES-6, MS-D462, Los Alamos National Laboratory, Los Alamos, NM 87545, U.S.A.
}

(Received January 9, 2001; Revised January 25, 2002; Accepted February 4, 2002)

\begin{abstract}
Geochemical and petrographic studies of the rhyolites and mafic inclusions from Satsuma-Iwojima volcano were carried out in order to investigate evolution of a silicic, bimodal magma system during the post-caldera stage. Abundant mafic inclusions, which are fine-grained with vesicles in their cores, are present in the ShowaIwojima rhyolitic lava. Inclusions with similar textures are found in Iwodake volcanic bombs but are less common than in the Showa-Iwojima lava. The major and trace element compositions of the inclusions plot along mixing lines connecting the host rhyolites with spatially and temporally associated basaltic to basaltic andesite magmas. Plagioclase phenocrysts in the inclusions have a large variation in core compositions ( $\mathrm{An}_{42}$ to $\left.\mathrm{An}_{96}\right)$, and exhibit various zoning profiles and reaction textures, indicating they coexisted with melts ranging from basaltic to rhyolitic composition. Pyroxenes also exhibit a wide range in composition and a variety of zoning patterns consistent with multiple sources. These results suggest that a stratified magma chamber exists beneath the volcano, consisting of a lower basaltic layer, an upper rhyolitic layer and an episodically-present, thin middle layer of andesite. Variations in the chemistry of the Iwodake and Showa-Iwojima mafic inclusions suggest that multiple injections of very similar basaltic magma have occurred since the growth of the Iwodake dome. More extensive textural disequilibrium shows that the Showa-Iwojima rhyolites formed through more extensive interaction with mafic magma. The mafic-felsic interaction is consistent with degassing model of a magma chamber estimated by other researchers, which consists of degassing of upper rhyolitic magma by convection in a conduit and supply of a $\mathrm{CO}_{2}$-rich volatile phase from underlying basaltic magma to the rhyolitic magma.
\end{abstract}

\section{Introduction}

Quenched mafic to intermediate inclusions with complex mineral textures and zoning patterns have been observed at many volcanoes, providing empirical evidence for coexistence of diverse magmas (e.g., Eichelberger, 1975; Sakuyama, 1979; Bacon and Metz, 1984; Bacon, 1986; Koyaguchi, 1986a, b; Stimac and Pearce, 1992; Tomiya and Takahashi, 1995; Pallister et al., 1996; Clynne, 1999). Interaction of mafic magma with silicic magma is accepted not only as an important control on the chemical and textural diversity of igneous rocks, but also as one of the dominant processes leading to the eruption of the silicic magma (Eichelberger, 1980). Injection of volatile-rich mafic magma into the base of a silicic magma chamber might initiate magma convection and various styles of mixing in the chamber due to heat exchange and vesiculation of the mafic magma (Eichelberger, 1980; Thomas et al., 1993). In the 1991 Mount Pinatubo eruption, the existence of a gas phase in the magma chamber before the eruption was inferred (Wallace and Gerlach, 1994; Gerlach et al., 1996), and the ultimate origin of the volatiles was considered to be an underlying mafic magma beneath the dacite magma

Copy right (C) The Society of Geomagnetism and Earth, Planetary and Space Sciences (SGEPSS); The Seismological Society of Japan; The Volcanological Society of Japan; The Geodetic Society of Japan; The Japanese Society for Planetary Sciences.
(Hattori, 1993). In this paper we present evidence for mafic magma contributing significant volatiles to an overlying silicic magma chamber at Satsuma-Iwojima volcano, Japan.

Satsuma-Iwojima volcano is characterized by high-volume passive degassing and bimodal eruption of basaltic and rhyolitic magmas within a small area and short time. The bimodal activity as well as abundant quenched mafic inclusions in the Showa-Iwojima rhyolitic lava erupted from 1934-1935 indicates that basaltic and rhyolitic magmas coexisted beneath the volcano (Goff et al., 1994). This observation should provide constraints on how basalt-rhyolite magma interactions affect volatile emissions and eruptive activity during post-caldera volcanism. In this study, geochemical and petrographic analyses of the mafic inclusions and their host rocks were conducted in order to improve our understanding of the evolution of the Satsuma-Iwojima magmatic system during the post-caldera stage.

\section{Geological Background}

\subsection{Geology}

Satsuma-Iwojima is a volcanic island, located on the rim of the largely submerged Kikai caldera in southwestern Japan (Fig. 1). Its pre-caldera volcanic activity probably began at less than $0.7 \mathrm{Ma}$, producing basaltic and rhyolitic eruptions (Ono et al., 1982). Multiple large caldera-forming eruptions began at least 77,000 y.B.P. based on thermolu- 


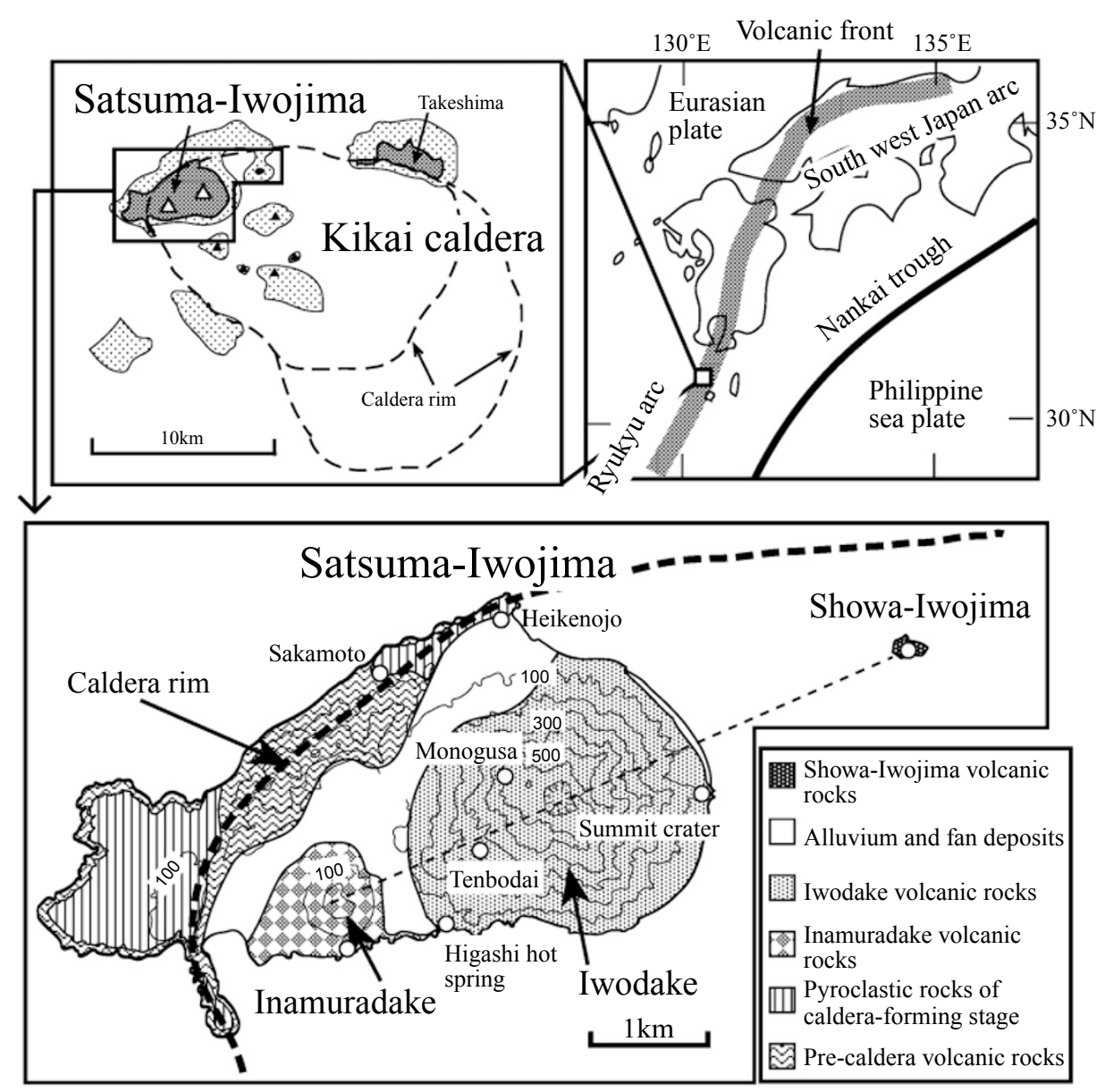

Fig. 1. Location maps of Kikai caldera and Satsuma-Iwojima volcano, Japan. Dark-shaded areas in the upper left figure indicate two islands on the caldera rim and the dotted areas indicate a depth less than $100 \mathrm{~m}$ beneath sea level. Closed triangles show submarine rises that are thought to be lava domes from the post-caldera stage. In the lower figure, post-caldera volcanoes and distribution of the volcanic rocks on Satsuma-Iwojima are shown after Ono et al. (1982). The thin dashed line connects the three vents of the post-caldera volcanoes, showing that they are parallel to the caldera fault and may be part of a ring fracture. Open circles indicate sampling points in this study.

minescence dating of volcanic ash from the second calderaforming event (Takamiya and Nishimura, 1986). The latest caldera-forming eruption produced the Takeshima pyroclastic flow deposit about 6500 y.B.P. (Kitagawa et al., 1995). This eruption created a stratigraphic marker called the "Akahoya" layer, which is found throughout Japan. Its total volume is estimated to be more than $100 \mathrm{~km}^{3}$ (Machida and Arai, 1978).

Both basaltic and rhyolitic eruptions occurred contemporaneously during the post-caldera stage along the northwestern part of the caldera, forming the rhyolitic dome of Iwodake (700 m high), and the scoria cone of Inamuradake (250 m high; Fig. 1). Despite their contrasting chemical composition, these post-caldera volcanoes grew only $2 \mathrm{~km}$ apart. Inamuradake consists of a scoria cone with preceding and contemporaneous basaltic lava flows (South and East lavas), and a later basaltic andesite lava (Isomatsuzaki lava). Eruptive activity at Inamuradake ceased about 3000 y.B.P., and that of Iwodake apparently ceased 1300 y.B.P. (Ono et al., 1982). However, recent carbon-14 dating of the Iwodake pyroclastic flow deposits indicates that small eruptions at Iwodake continued to 500 y.B.P. (Kawanabe and Saito, 2002). More recently, submarine eruption of rhyolitic magma occurred in 1934-1935 about $2 \mathrm{~km}$ east of the main island (Fig. 1). This eruption formed the small volcanic island named Showa-Iwojima. These three vents form a line subparallel to the caldera rim.

Some submarine rises were also observed on the floor of the Kikai caldera by bathymetry and interpreted as submarine lava domes formed during the post-caldera stage (Ono et al., 1982). The total volume of the magma erupted during the post-caldera stage (the last $\sim 6000$ years) is estimated to be more than $45 \mathrm{~km}^{3}$ from topographic constraints (Saito et al., 2001). This implies a magma effusion rate of $\sim 7.5 \mathrm{~km}^{3} / 1000$ years, which is very high compared to a range of average eruption rates of late Quaternary volcanoes in the Japanese arc $\left(0.1-1 \mathrm{~km}^{3} / 1000\right.$ years; Ono, 1990) or the average worldwide rate of silicic magma production ( $1 \mathrm{~km}^{3} / 1000$ years; Shaw, 1985). These high apparent effusion rates suggest that a large magma chamber has existed beneath the caldera during the post-caldera stage (Saito et al., 2001).

At present, Satsuma-Iwojima volcano has been passively discharging a large amount of high temperature volcanic gases from the summit crater of Iwodake. Sulfur dioxide flux measured by COSPEC is almost constant with an aver- 
Table 1. Summary of Satsuma-Iwojima volcanic rocks analyzed in this study.

\begin{tabular}{cl}
\hline Sample No. & \multicolumn{1}{c}{ Sample description } \\
\hline Inamuradake eruption (ca. 3000 y.B.P.) \\
N-1 & Bomb from cinder cone under South lava \\
N-2 & South lava \\
N-3 & South lava \\
N-4 & Inamuradake scoria \\
Iwodake eruption (6500-1300 y.B.P.) \\
I-1 & Iwodake volcanic bomb \\
I-2 & Iwodake volcanic bomb \\
I-3 & Iwodake pumice \\
I-4 & Iwodake lava \\
I-5 & Iwodake lava \\
I-6 & Iwodake lava \\
I-7 & Iwodake lava \\
I-8 & Iwodake lava \\
IM-1 & A mafic inclusion in I-1 $(4 \times 3 \mathrm{~cm})$ \\
IM-2 & A mafic inclusion in I-2 $(5 \times 3 \mathrm{~cm})$ \\
IM-3 & A mafic inclusion in Iwodake volcanic bomb $(1 \times 1 \mathrm{~cm})$ \\
Showa-Iwojima eruption (1934-1935) \\
S-1 & Rhyolitic lava \\
S-2 & Rhyolitic lava \\
S-3 & Rhyolitic lava \\
S-4 & Rhyolitic lava \\
SM-1 & A mafic inclusion in lava $(14 \times 7 \mathrm{~cm})$ \\
SM-2 & A mafic inclusion in lava $(9 \times 5 \mathrm{~cm})$ \\
SM-3 & A mafic inclusion in lava $(6 \times 5 \mathrm{~cm})$ \\
SM-4 & A mafic inclusion in lava \\
SM-5 & A mafic inclusion in lava $(9 \times 5 \mathrm{~cm})$ \\
\hline
\end{tabular}

All Inamuradake samples were collected at south side of Inamuradake cone, except for N-4 which was collected in air-fall scoria layer at Sakamoto. Iwodake samples of I-1 and IM-1 were collected at Heikenojo. Iwodake samples of I-2 to 3 and IM-2 to 3 were collected at Tenbodai. An Iwodake sample of I-4 was collected at Monogusa. Iwodake samples of I-5 to 7 were collected at east end of the island. An Iwodake sample of I-8 was collected near Higashi hot spring. Ages of I-2 to 8, IM-2 and IM-3 are ca. 1300 y.B.P. and those of I-1 and IM-1 are older than Inamuradake eruption (ca. 3000 y.B.P.) based on field observations.

age of $550 \mathrm{t} / \mathrm{d}$ since 1975 (Kazahaya et al., 2002). Intense fumarolic activity at the summit area of Iwodake has probably continued for more than 800 years according to old literature (Kamada, 1964). Most of the volatile components in the high temperature volcanic gases are believed to be of magmatic origin based on their chemical and isotopic compositions (Shinohara et al., 1993; Hedenquist et al., 1994; Goff and McMurtry, 2000). Volatile compositions of melt inclusions in the basalt and rhyolite suggests that the magmatic gas emissions result from degassing of the rhyolitic magma at a shallow depth, with the deeper basaltic magma supplying volatiles to the upper rhyolitic magma (Saito et al., 2001). Convection of rhyolitic magma in a conduit was proposed as the mechanism of magmatic gas transport from a deep magma chamber to the near surface (Kazahaya et al.,
2002).

\subsection{Petrography}

The volcanic rocks of the post-caldera stage show bimodal whole-rock chemistry consisting of basalt to basaltic andesite $\left(\mathrm{SiO}_{2}: 52-55\right.$ wt.\%) and rhyolite $\left(\mathrm{SiO}_{2}: 70-72\right.$ wt.\%; Ono et al., 1982). The rhyolites contain 7-14 vol\% plagioclase phenocrysts, $0.3-1.6$ vol\% of clinopyroxene, $0.4-1.1 \mathrm{vol} \%$ of orthopyroxene, and $0.1-1.1 \mathrm{vol} \%$ of magnetite and ilmenite (Ono et al., 1982). They also contain variable amounts of tiny pyrrhotite phenocrysts and globules, and oxide globules. The presence of pyrrhotite was previously described by Ueda and Itaya (1981), and the origin and significance of these phases was discussed by Larocque et al. (2000). Goff et al. (1994) mentioned that the Showa-Iwojima rhyolitic lava has abundant quenched mafic 


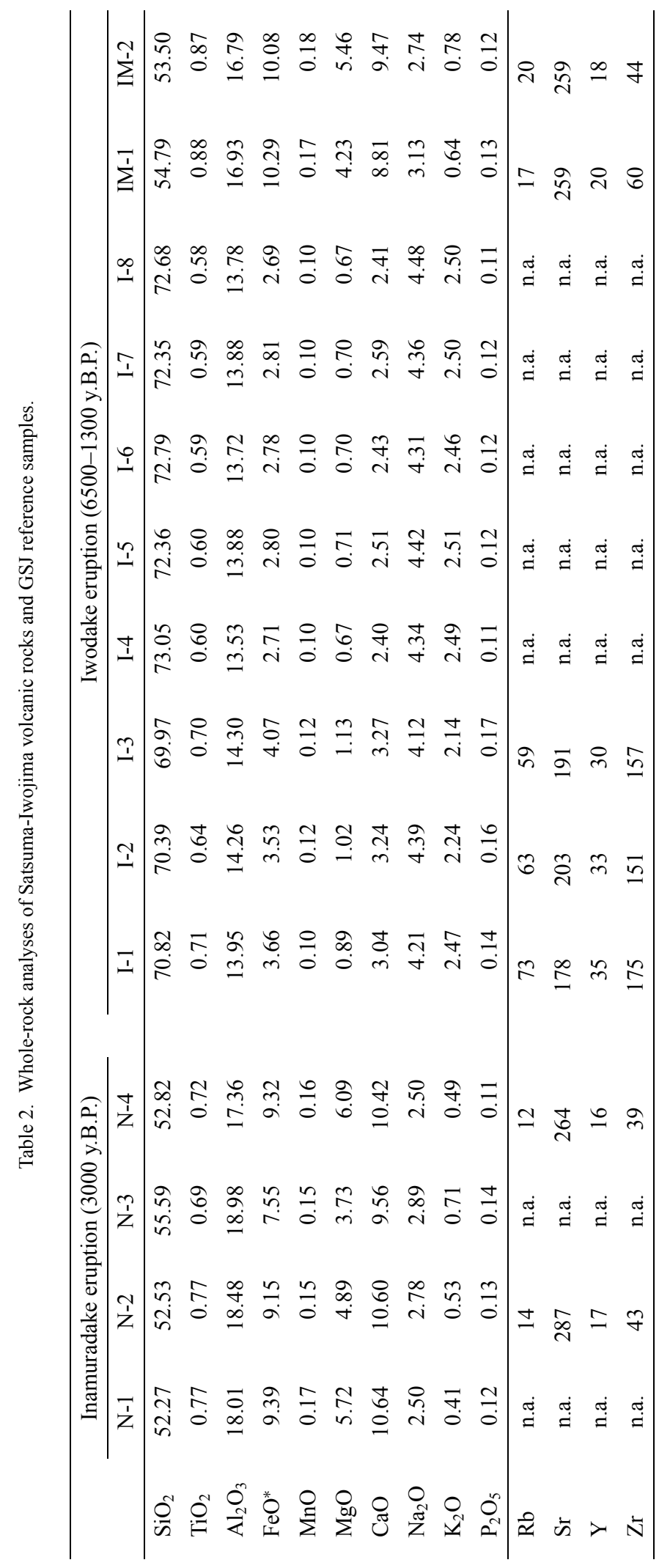




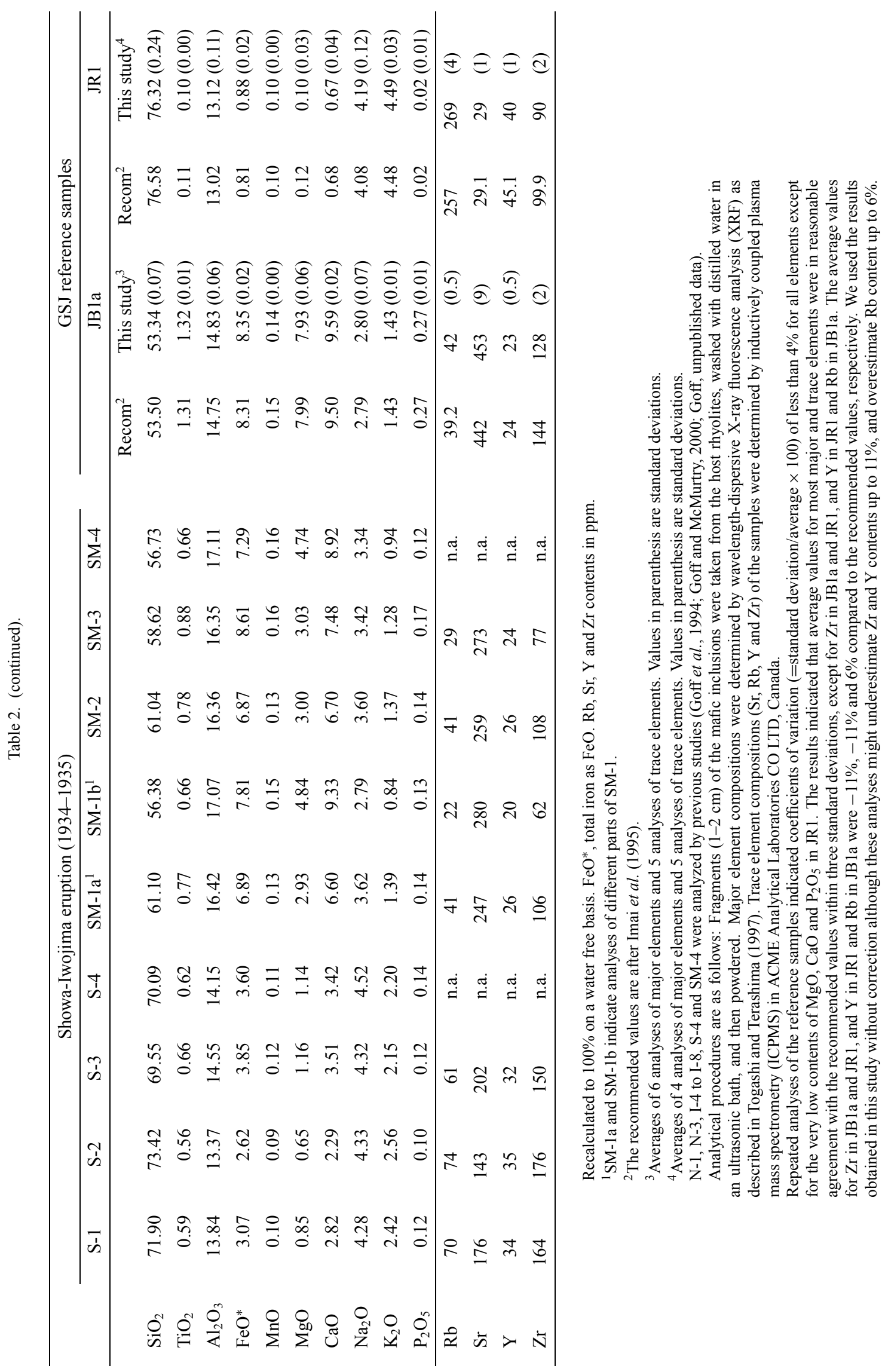


Table 3(a). Representative microprobe analyses of minerals in Iwodake mafic inclusions.

\begin{tabular}{lrrrrrrrr}
\hline & \multicolumn{9}{c}{ PLAG } & \multicolumn{1}{c}{ OPX } & \multicolumn{2}{c}{ CPX } \\
\cline { 2 - 6 } & \multicolumn{1}{c}{1} & \multicolumn{1}{c}{2} & \multicolumn{1}{c}{3} & \multicolumn{1}{c}{4} & \multicolumn{1}{c}{5} & \multicolumn{1}{c}{6} & \multicolumn{1}{c}{7} & \multicolumn{1}{c}{8} \\
\hline $\mathrm{SiO}_{2}$ & 46.78 & 50.21 & 55.60 & 49.09 & 51.99 & 55.98 & 52.84 & 48.93 \\
$\mathrm{TiO}_{2}$ & 0.04 & 0.04 & 0.04 & 0.00 & 0.03 & 0.05 & 0.19 & 0.83 \\
$\mathrm{Al}_{2} \mathrm{O}_{3}$ & 33.50 & 30.93 & 27.40 & 31.51 & 29.80 & 27.38 & 0.61 & 5.44 \\
$\mathrm{Cr}_{2} \mathrm{O}_{3}$ & 0.00 & 0.00 & 0.03 & 0.00 & 0.00 & 0.00 & 0.01 & 0.02 \\
$\mathrm{FeO}$ & 0.64 & 0.93 & 0.51 & 0.76 & 0.90 & 0.72 & 22.30 & 9.48 \\
$\mathrm{MnO}$ & 0.01 & 0.02 & 0.00 & 0.01 & 0.00 & 0.00 & 0.99 & 0.22 \\
$\mathrm{MgO}$ & 0.08 & 0.12 & 0.08 & 0.11 & 0.13 & 0.10 & 22.11 & 14.36 \\
$\mathrm{CaO}$ & 17.32 & 14.21 & 10.39 & 15.19 & 13.49 & 10.58 & 1.32 & 19.29 \\
$\mathrm{Na} 2 \mathrm{O}$ & 1.51 & 2.92 & 5.21 & 2.69 & 3.71 & 5.20 & 0.03 & 0.22 \\
$\mathrm{~K}_{2} \mathrm{O}$ & 0.02 & 0.08 & 0.25 & 0.07 & 0.11 & 0.18 & 0.00 & 0.01 \\
$\mathrm{Total}$ & 99.91 & 99.45 & 99.49 & 99.43 & 100.17 & 100.18 & 100.39 & 98.79 \\
\hline
\end{tabular}

$\mathrm{PLAG}=$ plagioclase, $\mathrm{OPX}=$ orthopyroxene, $\mathrm{CPX}=$ clinopyroxene.

Analyses: 1 and 2, plagioclase phenocryst core $\left(\mathrm{An}_{86.3}\right)$ and rim $\left(\mathrm{An}_{72.9}\right)$ in IM-1. 3 and 4, plagioclase phenocryst core $\left(\mathrm{An}_{52.4}\right)$ and rim $\left(\mathrm{An}_{75.8}\right)$ in IM-1. 5 and 6, plagioclase microphenocryst core $\left(\mathrm{An}_{66.7}\right)$ and rim $\left(\mathrm{An}_{52.9}\right)$ in groundmass of IM-1. 7, orthopyroxene phenocryst core $\left(\mathrm{Wo}_{2.7} \mathrm{En}_{62.2} \mathrm{Fs}_{35.2}, \mathrm{Mg} \# 63.9\right)$ in IM-1. 8, clinopyroxene phenocryst core $\left(\mathrm{Wo}_{41.3} \mathrm{En}_{42.8} \mathrm{Fs}_{15.9}, \mathrm{Mg} \# 73.0\right)$ in IM-2.

The analytical conditions were as follows: Accelerating voltage of $15 \mathrm{keV}$, beam current of $12 \mathrm{nA}$, an electron beam of $2 \mu \mathrm{m}$ diameter, and counting times of $20 \mathrm{sec}$. The absolute abundance of elements was obtained after Bence and Albee correction of the X-ray intensities. Standards were quartz for $\mathrm{Si}$, rutile for Ti, corundum for $\mathrm{Al}$, chromium oxide for Cr, hematite for $\mathrm{Fe}$, manganese oxide for $\mathrm{Mn}$, periclase for $\mathrm{Mg}$, wollastonite for $\mathrm{Ca}$ and adularia for $\mathrm{Na}$ and $\mathrm{K}$.

Repeated analyses of reference materials of plagioclase (An 68.6 , Lake Country, OR, USNM115900, Jarosewich et al., 1980), chromium augite $\left(\mathrm{En}_{53.5} \mathrm{Fs}_{8.1} \mathrm{Wo}_{38.4}, \mathrm{Mg} \# 86.8\right.$, Black Rock Summit Flow, Lunar Craters Lava Field, Nye Country, Nevada, NMNH164905, Jarosewich et al., 1987) and olivine (Fo90.2Fa9.8, San Carlos, Arizona, Smithsonian\#136718, Chakraborty et al., 1994) gave $\operatorname{An}_{67.1}(1 \sigma=0.7)$ for the plagioclase, $\operatorname{En}_{53.4}(1 \sigma=0.5) \mathrm{Fs}_{7.9}(1 \sigma=0.2) \mathrm{Wo}_{38.7}(1 \sigma=0.6)$ and $\mathrm{Mg} \# 87.1(1 \sigma=0.3)$ for the augite, and $\operatorname{Fog90}_{9.5}(1 \sigma=0.1) \mathrm{Fa}_{9.5}(1 \sigma=0.1)$, respectively. The results indicate that precision was good and the averages were within two standard deviations from the recommended values except for olivine.

Table 3(b). Representative microprobe analyses of minerals in Showa-Iwojima mafic inclusions.

\begin{tabular}{|c|c|c|c|c|c|c|c|c|c|c|c|c|}
\hline & \multicolumn{8}{|c|}{ PLAG } & \multirow{2}{*}{$\begin{array}{c}\text { OPX } \\
9\end{array}$} & \multicolumn{2}{|c|}{ CPX } & \multirow{2}{*}{$\begin{array}{c}\text { OL } \\
12\end{array}$} \\
\hline & 1 & 2 & 3 & 4 & 5 & 6 & 7 & 8 & & 10 & 11 & \\
\hline $\mathrm{SiO}_{2}$ & 45.05 & 50.02 & 56.78 & 52.32 & 50.78 & 57.01 & 49.90 & 51.75 & 53.76 & 52.77 & 51.68 & 39.50 \\
\hline $\mathrm{TiO}_{2}$ & 0.01 & 0.08 & 0.00 & 0.03 & 0.04 & 0.05 & 0.00 & 0.04 & 0.20 & 0.19 & 0.48 & 0.02 \\
\hline $\mathrm{Al}_{2} \mathrm{O}_{3}$ & 34.28 & 30.47 & 27.32 & 29.88 & 30.83 & 27.42 & 31.20 & 30.81 & 0.55 & 2.21 & 1.60 & 0.01 \\
\hline $\mathrm{Cr}_{2} \mathrm{O}_{3}$ & 0.03 & 0.01 & 0.01 & 0.00 & 0.01 & 0.01 & 0.00 & 0.00 & 0.00 & 0.18 & 0.00 & 0.00 \\
\hline $\mathrm{FeO}$ & 0.61 & 0.84 & 0.56 & 0.69 & 0.62 & 0.58 & 0.76 & 0.72 & 19.87 & 5.39 & 11.35 & 17.52 \\
\hline $\mathrm{MnO}$ & 0.00 & 0.00 & 0.00 & 0.02 & 0.00 & 0.01 & 0.00 & 0.01 & 1.22 & 0.07 & 0.44 & 0.31 \\
\hline $\mathrm{MgO}$ & 0.10 & 0.11 & 0.06 & 0.05 & 0.04 & 0.03 & 0.18 & 0.08 & 23.34 & 16.72 & 14.28 & 42.65 \\
\hline $\mathrm{CaO}$ & 18.30 & 14.15 & 10.09 & 13.05 & 14.50 & 10.01 & 15.25 & 14.08 & 1.18 & 21.66 & 19.44 & 0.16 \\
\hline $\mathrm{Na}_{2} \mathrm{O}$ & 1.15 & 3.23 & 5.60 & 4.04 & 3.22 & 4.95 & 2.77 & 3.27 & 0.00 & 0.14 & 0.26 & 0.00 \\
\hline $\mathrm{K}_{2} \mathrm{O}$ & 0.02 & 0.07 & 0.24 & 0.12 & 0.09 & 0.28 & 0.08 & 0.09 & 0.00 & 0.0 & 0.01 & 0.00 \\
\hline Total & 99.54 & 98.98 & 100.64 & 100.20 & 100.13 & 100.34 & 100.13 & 100.85 & 100.14 & 99.3 & 99.57 & 100.17 \\
\hline
\end{tabular}

$\mathrm{PLAG}=$ plagioclase, $\mathrm{OPX}=$ orthopyroxene, $\mathrm{CPX}=$ clinopyroxene, $\mathrm{OL}=$ olivine.

Analyses: 1 and 2, plagioclase phenocryst core $\left(\mathrm{An}_{89.8}\right)$ and rim $\left(\mathrm{An}_{70.8}\right)$ in $\mathrm{SM}-1.3$ and 4, plagioclase phenocryst core $\left(\mathrm{An}_{49.9}\right)$ and rim $(\mathrm{An} 64.1)$ in SM-5. 5 and 6, plagioclase phenocryst core $\left(\mathrm{An}_{71.3}\right)$ and rim $\left(\mathrm{An}_{52.8}\right)$ in $\mathrm{SM}-1.7$, plagioclase microphenocryst core $\left(\mathrm{An}_{75.3}\right)$ in groundmass of SM-1. 8, plagioclase microphenocryst core $\left(\mathrm{An}_{70.4}\right)$ in groundmass of SM-3. 9, orthopyroxene phenocryst core $\left(\mathrm{Wo}_{2.4} \mathrm{En}_{66.1} \mathrm{Fs}_{31.5}, \mathrm{Mg}_{367.7)}\right.$ in SM-5. 10, clinopyroxene phenocryst core $\left(W_{44.1} E_{47.3} F_{8} 8.6, M g \# 84.7\right)$ in SM-1. 11, clinopyroxene phenocryst core $\left(\mathrm{Wo}_{40.4} \mathrm{En}_{41.2} \mathrm{Fs}_{18.4}, \mathrm{Mg}\right.$ 69.2) in SM-1. 12, olivine phenocryst core (Mg\#81.3) in SM-1. 

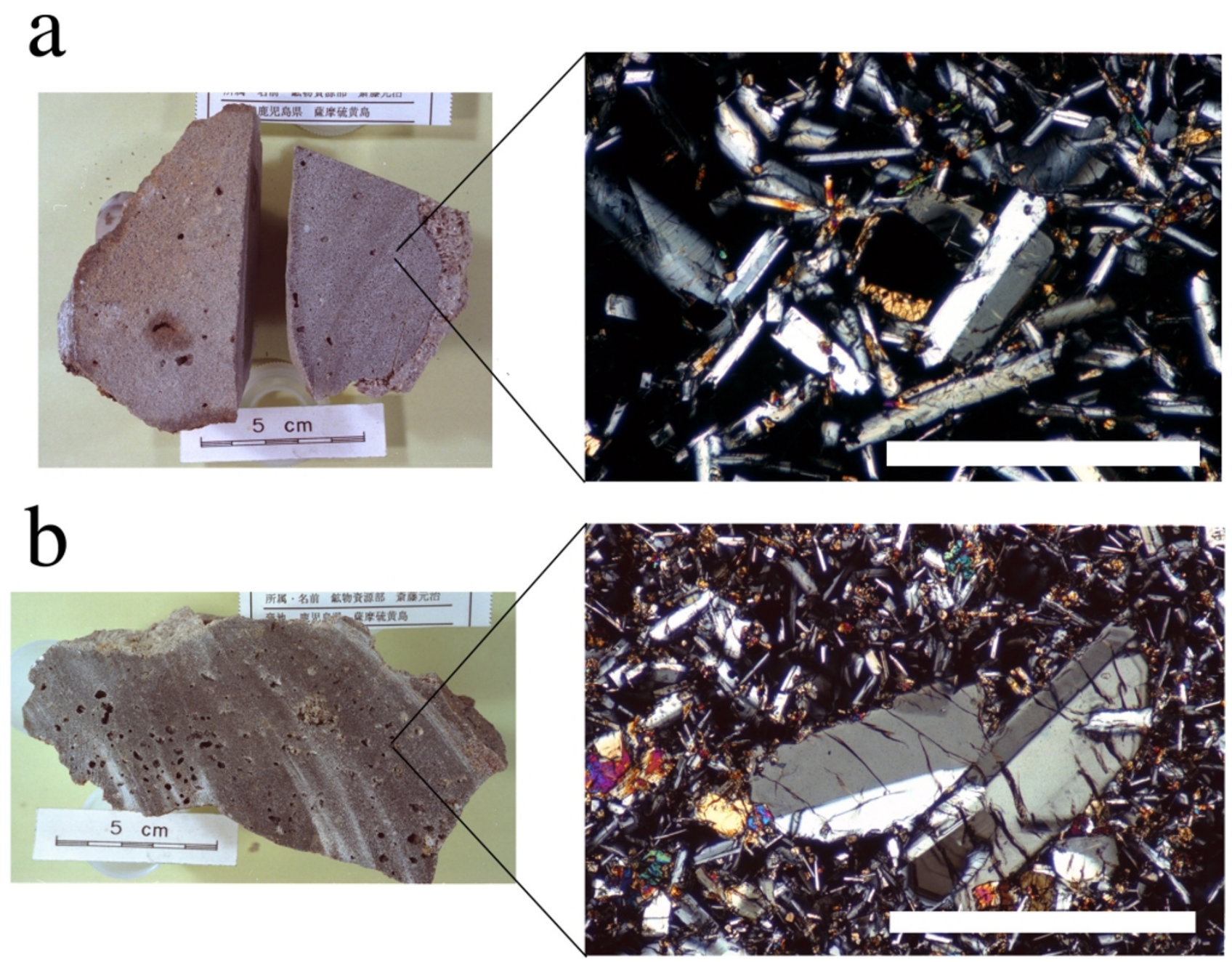

Fig. 2. Photographs of mafic inclusions. a) Mafic inclusion SM-2 in Showa-Iwojima rhyolitic lava. b) Mafic inclusion SM-1 in Showa-Iwojima rhyolitic lava. Photomicrographs (right) were taken with crossed nicols. Microphenocrysts in groundmass in SM-2 are larger than those of SM-1. Scale bars $=1 \mathrm{~mm}$.

inclusions as described below. The Inamuradake basaltic scoria contains $23 \mathrm{vol} \%$ plagioclase phenocrysts, and 2.5 vol $\%$ of clinopyroxene, $0.9 \mathrm{vol} \%$ of orthopyroxene, 1.7 vol $\%$ of olivine, and 0.8 vol\% of FeTi oxide (Ono et al., 1982). Some samples of thin flow layers collected by Goff et al. (1994) are more evolved $\left(\sim 55 \mathrm{wt} \% \mathrm{SiO}_{2}\right)$, contain plagioclase exhibiting fritted texture, and lack olivine phenocrysts.

\section{Samples}

Abundant quenched mafic inclusions were observed in Showa-Iwojima rhyolitic lava (Figs. 1 and 2). The ShowaIwojima mafic inclusions are dark-colored and up to $20 \mathrm{~cm}$ in length. They are typically spherical to oblate in shape, and some inclusions have crenulate margins. All inclusions have a fine-grained, diktytaxitic groundmass and vesicles of up to $5 \mathrm{~mm}$ in diameter in their cores (Fig. 2). These features are similar to mafic to intermediate inclusions described from other silicic lava flows and domes, and indicate that the inclusions were predominantly liquid when they were engulfed by the rhyolitic magma (e.g., Heiken and Eichelberger, 1980; Bacon and Metz, 1984; Bacon,
1986; Linneman and Myers, 1990; Clynne, 1999). Microscopic observations and chemical analyses were carried out on five mafic inclusions in Showa-Iwojima lava (Table 1 and Fig. 1). Inclusions SM-1 and SM-5 have $\sim 15$ and 5 vol $\%$ phenocrysts respectively, of plagioclase, clinopyroxene, orthopyroxene, olivine and FeTi oxides (Fig. 2). The plagioclase phenocrysts are up to $2 \mathrm{~mm}$ long; the others are up to $1 \mathrm{~mm}$. Some plagioclase phenocrysts have dusty zones of melt inclusions in their cores or rims. The groundmass consists of tiny plagioclase, clinopyroxene, and orthopyroxene up to $0.2 \mathrm{~mm}$, FeTi oxides and pyrrhotite, with interstitial glass. Pyrrhotite occurs as globules and as tubular microphenocrysts (cf. Ueda and Itaya, 1981). Inclusions SM-2 and SM-3 have $<5$ vol\% phenocrysts with a groundmass consisting of tiny plagioclase, clinopyroxene and orthopyroxene. The microphenocrysts in the groundmass are up to $0.5 \mathrm{~mm}$, which is larger than those in inclusions SM-1 and SM-5 (Fig. 2).

Some small mafic inclusions were found in Iwodake volcanic bombs (Table 1$)$, but they are rare $(\ll 1$ vol\%) compared to those in the Showa-Iwojima lava. These inclusions have similar shapes and textures to those of the Showa- 

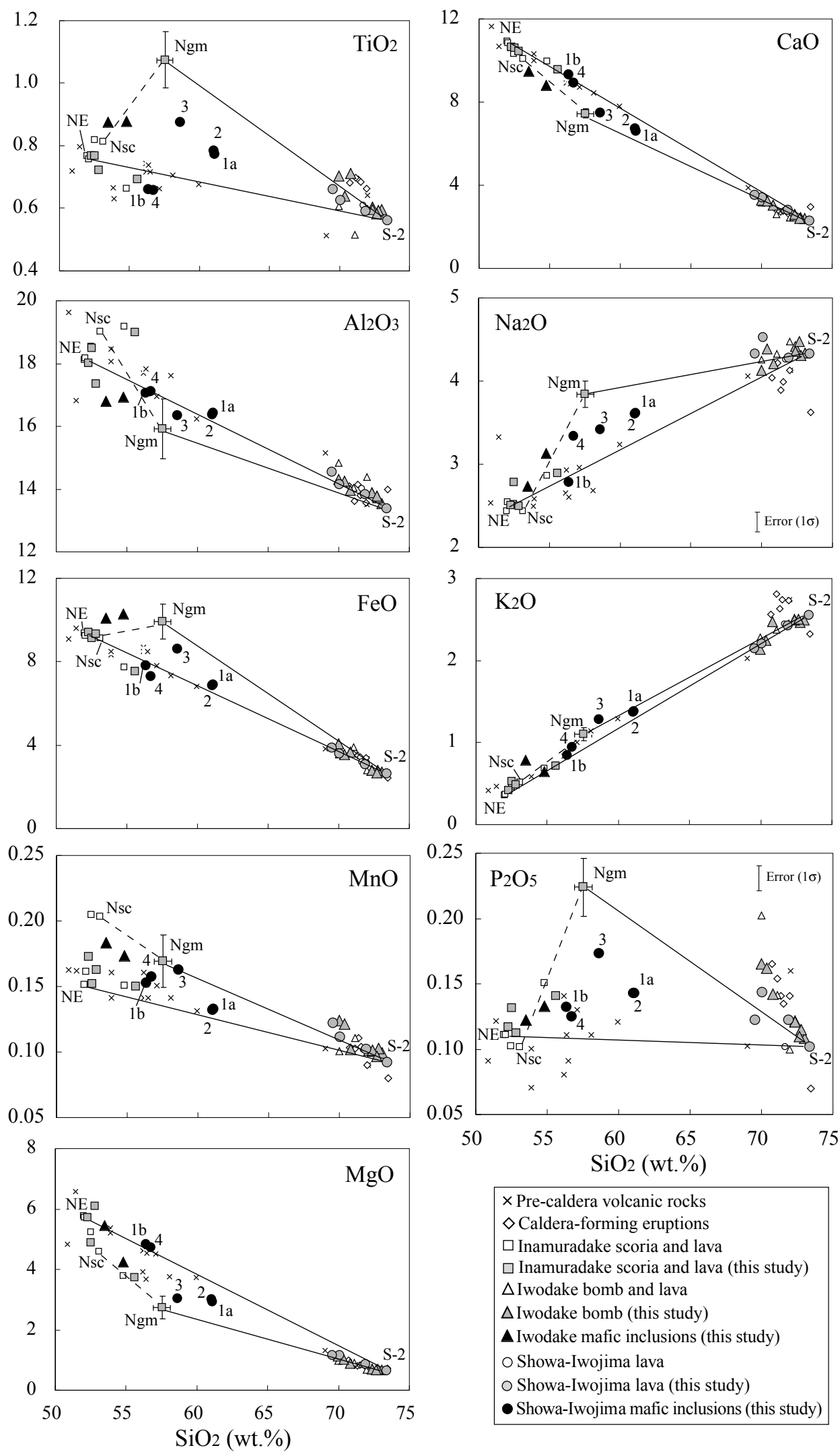

$\times$ Pre-caldera volcanic rocks

$\diamond$ Caldera-forming eruptions

$\square$ Inamuradake scoria and lava

$\square$ Inamuradake scoria and lava (this study)

$\triangle$ Iwodake bomb and lava

$\triangle$ Iwodake bomb (this study)

$\Delta$ Iwodake mafic inclusions (this study)

o Showa-Iwojima lava

O Showa-Iwojima lava (this study)

- Showa-Iwojima mafic inclusions (this study)

Fig. 3. Major element variation diagrams for Iwodake and Showa-Iwojima volcanic rocks and mafic inclusions. All data were recalculated on a water-free basis. Uncertainty of analyses is less than the symbol size. The solid triangles and circles denote compositions of mafic inclusions from Iwodake and Showa-Iwojima, respectively. The whole-rock compositions of pre-caldera (cross symbol), caldera-formation (open diamonds), Inamuradake (open squares), Iwodake (open triangles) and Showa-Iwojima (open circles) volcanic rocks (Ono et al., 1982; Ujike et al., 1986) are also shown. Gray colored squares, triangles and circles are chemical compositions of Inamuradake, Iwodake and Showa-Iwojima volcanic rocks, respectively, obtained in this study. The gray square with error bars (Ngm) indicates the chemical composition of groundmass of Inamuradake scoria (Saito et al., 2001). The error bars indicate 1 standard deviation. Broken lines connect the groundmass and the whole-rock composition of the Inamuradake scoria (Nsc). 

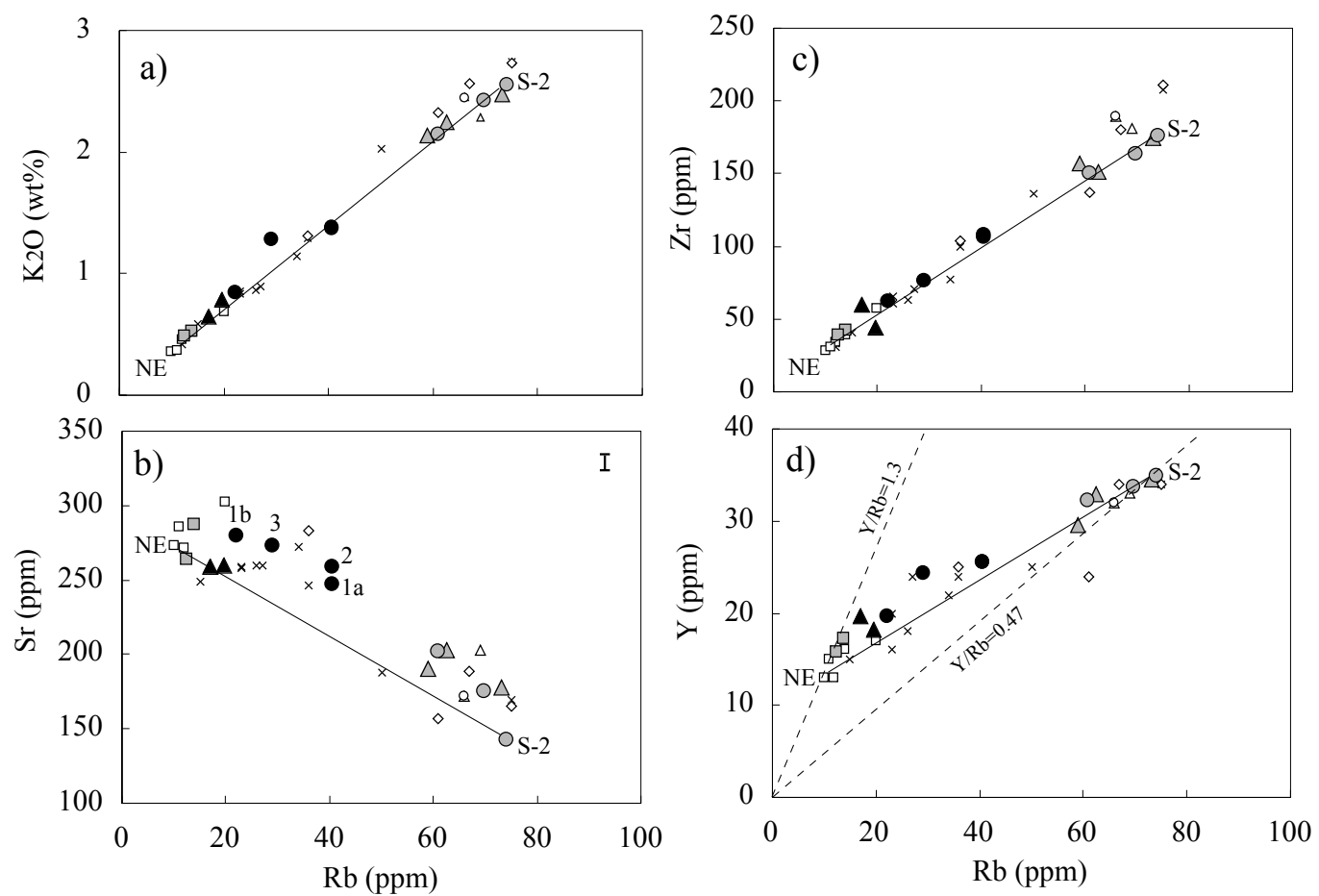

Fig. 4. Trace element composition of the Iwodake and Showa-Iwojima volcanic rocks and mafic inclusions of Satsuma-Iwojima volcano. Symbols are as in Fig. 3. The whole-rock compositions of pre-caldera, caldera-formation, Inamuradake, Iwodake and Showa-Iwojima volcanic rocks (Ono et al., 1982; Ujike et al., 1986) are also shown. An error bar indicates the standard deviation of Sr analyses. Standard deviations for the other element analyses are similar or less than symbol size. Solid lines indicate a mixing line between sample S-2 and East lava formed during Inamuradake eruption (NE).

Iwojima rhyolites, but only range up to $5 \mathrm{~cm}$ in length (Table 1). This distribution and size range is similar to that reported for the rhyolite of Thurston Creek at Clear Lake, CA (Stimac et al., 1990). At least one lava flow on the east side of Iwodake contains larger and more abundant inclusions $(<1-5 \mathrm{vol} \%)$, but the amount of entrained intermediate magma in the Iwodake eruptions is generally $<1 \mathrm{vol} \%$. Most inclusions are very fine-grained as a consequence of their small size. Microscopic observations and chemical analyses were carried out on three larger mafic inclusions in the bombs (Table 1). The inclusions have sparse plagioclase, clinopyroxene and orthopyroxene phenocrysts ( $<5 \mathrm{vol} \%)$. The groundmass has tiny plagioclase, clinopyroxene and orthopyroxene (up to $0.5 \mathrm{~mm}$ ), and FeTi oxides $(<0.1 \mathrm{~mm}$ ) set in interstitial glass. Rare pyrrhotite is present as inclusions in phenocrysts. Iwodake samples I-1 and IM-1 are from volcanic bombs erupted 6500-3000 y.B.P., and the other samples are products of the eruption at $\sim 1300$ y.B.P.

Whole-rock samples of two Iwodake mafic inclusions, three Showa-Iwojima mafic inclusions, their host rhyolites and Inamuradake basalts were analyzed for their major and trace element compositions (Table 2). Repeated analyses of rock standards JB1a and JR1, prepared by the Geological Survey of Japan (Imai et al., 1995), were also carried out (Table 2). Major element compositions of phenocrysts and groundmass microphenocrysts of three Iwodake mafic inclusions (Table 3(a)), four Showa-Iwojima mafic inclusions (Table 3(b)), their host rhyolites, and the Inamuradake scoria and lava, were analyzed by electron microprobe (JEOL JXA-8800 Superprobe).

\section{Results}

\subsection{Whole-rock composition}

Iwodake volcanic bombs and Showa-Iwojima lavas are of rhyolitic composition and are nearly identical to results of previous studies (Table 2 and Fig. 3; Ono et al., 1982; Ujike et al., 1986). In general, each rhyolite unit shows variation in major element composition, with their $\mathrm{TiO}_{2}, \mathrm{Al}_{2} \mathrm{O}_{3}, \mathrm{FeO}$, $\mathrm{MnO}, \mathrm{MgO}, \mathrm{CaO}$ and $\mathrm{P}_{2} \mathrm{O}_{5}$ contents becoming lower and $\mathrm{Na}_{2} \mathrm{O}$ content becoming higher as the $\mathrm{SiO}_{2}$ content increases from about 69.6 to $73.4 \mathrm{wt} \%$ (Table 2 and Fig. 3). All Iwodake and Showa-Iwojima rhyolite samples analyzed in this study plot along mixing lines between the Inamuradake scoria groundmass and the most evolved Showa-Iwojima rhyolite (S-2; Fig. 3). The Showa-Iwojima rhyolite contains matrix glass that is slightly more $\mathrm{SiO}_{2}$-rich than that of the Iwodake rhyolites. Saito et al. (2001) proposed that the difference could be explained by further crystallization of plagioclase in the rhyolitic magma chamber with time.

The mafic inclusions in the Iwodake and Showa-Iwojima rhyolites are characterized by basaltic to andesitic compositions, which are similar to those of basalt and andesite volcanic rocks erupted during the pre- and post-caldera stages (Fig. 3). Iwodake mafic inclusions have a similar or slightly more $\mathrm{SiO}_{2}$-rich composition than that of the Inamuradake basalt. These inclusions have slightly higher $\mathrm{FeO}, \mathrm{TiO}_{2}$ and $\mathrm{Na}_{2} \mathrm{O}$ contents and lower $\mathrm{Al}_{2} \mathrm{O}_{3}$ and $\mathrm{CaO}$ contents than the Inamuradake basalt, and their chemical compositions plot between Inamuradake scoria and scoria groundmass (Fig. 3). Showa-Iwojima mafic inclusions have more $\mathrm{SiO}_{2}$ rich compositions than Iwodake mafic inclusions and Ina- 
muradake basalt. They are similar to andesitic rocks formed during the pre-caldera stage, although inclusions SM-1a, SM-2 and SM-3 have slightly higher $\mathrm{TiO}_{2}, \mathrm{FeO}, \mathrm{Na}_{2} \mathrm{O}$ and $\mathrm{P}_{2} \mathrm{O}_{5}$ contents and lower $\mathrm{MgO}$ and $\mathrm{CaO}$ contents than those of the andesitic rocks (Fig. 3). They have a large variation of chemical compositions not only between inclusions but also within single inclusions (SM-1a and SM-1b in Table 2). Inclusions SM-1b and SM-4 plot along a mixing line between less evolved Inamuradake basalt (East lava; NE in Fig. 3) and the most silicic Showa-Iwojima rhyolite (S-2 in Fig. 3). On the other hand, inclusions SM-1a, SM-2 and SM-3 are more $\mathrm{TiO}_{2}$-rich, $\mathrm{P}_{2} \mathrm{O}_{5}$-rich and $\mathrm{MgO}$-poor than those of inclusions SM-1b and SM-4 and do not plot on the mixing line. They plot in an area defined by the end member compositions of NE, S-2 and the Inamuradake scoria groundmass (Ngm), and in particular SM-3 has a composition similar to the scoria groundmass (Fig. 3). The mafic inclusions appear to form a distinct mixing trend between rhyolites (S-2) and a basaltic end member that is intermediate in composition between the Inamuradake scoria (Nsc) and that of the scoria groundmass (Ngm) (Fig. 3).

Trace element compositions of the Iwodake and ShowaIwojima rhyolites containing mafic inclusions (Table 2 and Fig. 4) are similar to those of the rhyolites in SatsumaIwojima reported by a previous study (Ujike et al., 1986). Trace element compositions vary within each rhyolite (Fig. 4). They plot along mixing lines between the less evolved Inamuradake basalt (East lava; NE in Fig. 4) and the Showa-Iwojima rhyolite, S-2. The Iwodake mafic inclusions have similar trace as well as major element compositions as the Inamuradake basalt. Showa-Iwojima mafic inclusions have similar compositions as pre-caldera stage basaltic andesites, which show mixing trends between basalt and rhyolite (Ujike et al., 1986). Ratios of $\mathrm{Zr}$ to $\mathrm{Rb}$ and $\mathrm{K}_{2} \mathrm{O}$ to $\mathrm{Rb}$ in the mafic inclusions are almost constant, and are similar to those of the basaltic and rhyolitic magmas (Fig. 4). On the other hand, the ratio of $\mathrm{Y}$ to $\mathrm{Rb}$ for mafic inclusions changes from the Iwodake mafic inclusion (IM$1 ; 1.16)$ to the Showa-Iwojima mafic inclusion (SM-1a and SM-2; 0.63), reflecting the mixing trend between the basalt and the rhyolites. Variation in $\mathrm{Sr}$ and $\mathrm{Rb}$ contents of the Iwodake and Showa-Iwojima mafic inclusions also shows a mixing trend between Inamuradake magmas and the ShowaIwojima rhyolite (Fig. 4).

The rhyolitic magmas erupted during the post-caldera stage are believed to be derived from the same magma chamber on the basis of their similar mineral assemblage and major element (Saito et al., 2001), trace element (Ujike et al., 1986), and strontium isotopic compositions (Notsu et al., 1987). As argued by Notsu et al. (1987) the relatively constant and low ${ }^{87} \mathrm{Sr} /{ }^{86} \mathrm{Sr}$ ratios (0.70477 to 0.70496$)$ of caldera-forming and post-caldera rhyolites and basalts is consistent with the suite forming dominantly from fractional crystallization from a mafic parent similar to pre-caldera and post-caldera basalts. The slightly higher range of ${ }^{87} \mathrm{Sr} /{ }^{86} \mathrm{Sr}$ ratios for pre-caldera mafic rocks $(0.70485$ to 0.70539$)$ and positive correlation of this ratio with $\mathrm{Si}$ and $\mathrm{Rb}$ for some rocks suggests that the source region was inhomogeneous or that crustal melts were more influential during the precaldera stage. However, magma components during the caldera-forming and post-caldera stage formed from more thoroughly homogenized magma batches with lesser overall influence of these components. If melting of crustal material is invoked, then the ${ }^{87} \mathrm{Sr} /{ }^{86} \mathrm{Sr}$ ratios of the crustal material must be lower than exposed crustal rocks of southern Kyushu (Notsu et al., 1987).

\subsection{Chemical composition and zoning profiles of pla- gioclase in mafic inclusions}

Plagioclase phenocryst cores in the Iwodake and ShowaIwojima mafic inclusions have a large variation in composition (Table 3 and Fig. 5) from An\#42 to An\#96 (An\# = $\mathrm{Ca} /(\mathrm{Ca}+\mathrm{Na}) \times 100 \%)$. They can be classified in three groups depending on their core compositions: An-rich ( $>$ An\#80), intermediate An $(60<$ An\# $<80)$, and Abrich $(A n \#<60)$. The An-rich and Ab-rich phenocrysts comprise about $45 \%$ and $33 \%$ of the phenocrysts analyzed, respectively. The Showa-Iwojima mafic inclusions have various core compositions ranging from Ab-rich to An-rich through intermediate composition. On the other hand, the Iwodake mafic inclusions have only one phenocryst with core of An\#52 and the other five plagioclase phenocrysts have cores of An\#86-90. Phenocrysts in the host rhyolites and the Inamuradake basaltic scoria and lava have core compositions ranging from An\#44 to An\#70 and from An\#74 to An\#96, respectively (Fig. 5(a)). Microphenocrysts in the groundmass of Iwodake and Showa-Iwojima mafic inclusions have cores ranging from An\#60 to An\#80 (averaging about An\#70), which are similar to those of phenocryst rims of the Inamuradake basalt (Fig. 5). The distribution is different from cores of phenocrysts in the Inamuradake basalt, the rhyolites and the mafic inclusions.

Zoning profiles were analyzed for some phenocrysts in each An-rich (An\# > 80), intermediate An $(60<$ An\# $<$ $80)$, and Ab-rich (An\# < 60) group. Three types of zoning profiles were observed for the An-rich group. One type has flat zoning in its inner part and normal zoning at its rim (Fig. 6(a)). This zoning profile was observed in all four An-rich phenocrysts in the Iwodake mafic inclusions and in about $70 \%$ of An-rich phenocrysts in the Showa-Iwojima mafic inclusions. The second type displays chemical compositions that gradually become more $\mathrm{Ab}$-rich from core to rim (Fig. 6(c)). The third type shows drastic changes of the chemical composition (Fig. 6(b) and final calcic spike in 6(c)). These types were observed in phenocrysts in the Showa-Iwojima mafic inclusions.

Two types of zoning profiles were observed for the Abrich plagioclase phenocrysts. One type has flat zoning in its inner part and reverse zoning at the rim (Fig. 6(d)). This zoning profile was observed in one Ab-rich plagioclase phenocryst in the Iwodake mafic inclusion and in about 70\% of Ab-rich plagioclase phenocrysts in the Showa-Iwojima mafic inclusions. The other type shows oscillatory zoning with multiple An-rich bands (An\# 70), Ab-rich bands and sieved textures between core and rim (Fig. 6(e)), indicating cyclic changes of temperature or melt composition during crystallization (Tsuchiyama, 1985b).

Plagioclase phenocrysts with core compositions of An\#60-80 typically have normal zoning of their inner part and reverse zoning at the rim (Figs. 6(g) and (h)). This zoning profile was observed in about $60 \%$ of the plagioclase 

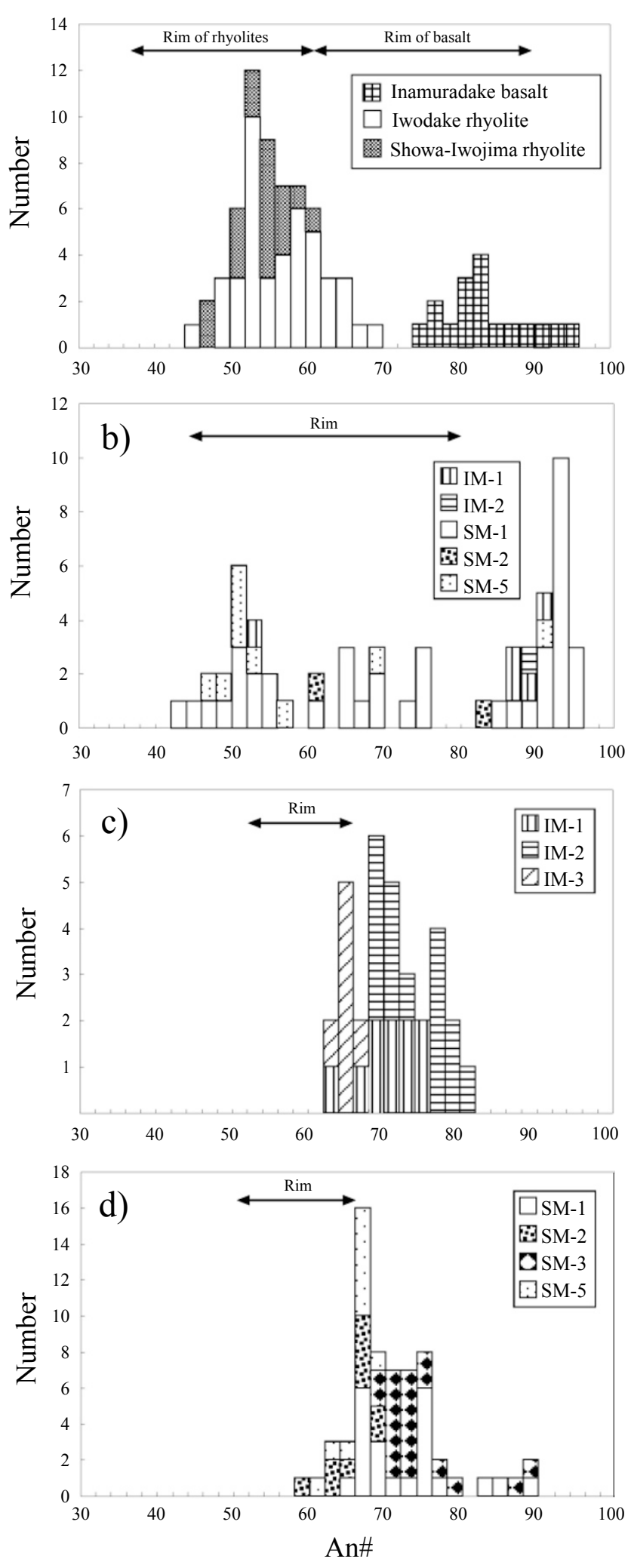

Fig. 5. Compositions of plagioclase phenocryst cores in the Iwodake and Showa-Iwojima mafic inclusions, their host rhyolites and Inamuradake basalt. Range of compositions of plagioclase phenocryst rims is shown by lines with arrows. An $\#=\mathrm{Ca} /(\mathrm{Ca}+\mathrm{Na}) \times 100$. a) Plagioclase phenocrysts in Inamuradake scoria and lava, Iwodake volcanic bombs and pumice and Showa-Iwojima lava. b) Plagioclase phenocrysts in the Iwodake and Showa-Iwojima mafic inclusions. c) Plagioclase microphenocrysts in groundmass of Iwodake mafic inclusions. d) Plagioclase microphenocrysts in groundmass of Showa-Iwojima mafic inclusions. phenocrysts with cores of An\#60-80. Some phenocrysts show oscillatory zoning with multiple An-rich bands (An\# 70), round Ab-rich bands and sieve-like textures between core and rim as well as the Ab-rich phenocrysts (Fig. 6(f)). These features suggest cyclic changes in the condition of crystallization.

\subsection{Chemical compositions of pyroxene and olivine in the mafic inclusions and post-caldera volcanic rocks}

Clinopyroxene phenocryst cores in Iwodake and ShowaIwojima rhyolites have partly overlapping compositional ranges with those of Inamuradake basalt (Fig. 7). Mg\# $(\mathrm{Mg} \#=\mathrm{Mg} /(\mathrm{Mg}+\mathrm{Fe}) \times 100 \%)$ of phenocryst cores in the rhyolites are slightly lower than in the basalt (Fig. 8). Orthopyroxene phenocryst cores from the rhyolites are more Mg-poor than those in Inamuradake basalt (Figs. 7 and 8). The pyroxene cores in the rhyolites also have lower $\mathrm{Al}_{2} \mathrm{O}_{3}$ contents than those in the Inamuradake basalt (Fig. 9).

Clinopyroxene phenocryst cores in Iwodake and ShowaIwojima mafic inclusions have chemical compositions of $\mathrm{Wo}_{40-45} \mathrm{En}_{41-47} \mathrm{Fs}_{9-18}$ (Fig. 7). The compositions are similar to those of Inamuradake basalt, and Iwodake and ShowaIwojima rhyolites (Table 3 and Fig. 7). Their Mg\# overlap both those of the Inamuradake basalt, and the rhyolites (Fig. 8). The cores have a large variation in $\mathrm{Al}_{2} \mathrm{O}_{3}$ content compared to those of the basalt and the rhyolites (Fig. 9). Orthopyroxene phenocrysts cores in mafic inclusions have chemical compositions of $\mathrm{Wo}_{2-3} \mathrm{En}_{62-67} \mathrm{Fs}_{31-35}$, which are similar to those of the rhyolites (Table 3 and Fig. 7), except for one orthopyroxene in Showa-Iwojima mafic inclusion $\left(\begin{array}{lll}\mathrm{Wo}_{2.8} & \mathrm{En}_{73.4} & \mathrm{Fs}_{23.7}\end{array}\right) . \mathrm{Mg} \#$ and $\mathrm{Al}_{2} \mathrm{O}_{3}$ contents (and their distribution) of the orthopyroxene cores are similar in inclusions and their host of the rhyolites (Figs. 8 and 9). Olivine phenocrysts in Showa-Iwojima mafic inclusions have core compositions of $\mathrm{Fo}_{74-82}$. The distribution of $\mathrm{Mg} \#$ of the olivine cores is slightly higher than that of the Inamuradake basalt (Fig. 10).

Line profiles of $\mathrm{Mg} \#$ and $\mathrm{Al}_{2} \mathrm{O}_{3}, \mathrm{TiO}_{2}, \mathrm{Cr}_{2} \mathrm{O}_{3}$ contents were analyzed for two clinopyroxene and two orthopyroxene phenocrysts in Iwodake mafic inclusions and ten clinopyroxene and nine orthopyroxene phenocrysts in Showa-Iwojima mafic inclusions. Three types of $\mathrm{Mg} \#$ line profiles were observed for the clinopyroxene phenocrysts. One type has flat zoning in its inner part and normal zoning (Figs. 11(a) and (b)) or a Mg-rich spike at its rim (Fig. 11(c)). This zoning profile was observed in six clinopyroxene phenocrysts in the Showa-Iwojima mafic inclusions and two clinopyroxene phenocrysts in Iwodake mafic inclusions. Three phenocrysts of a second type show gradual reverse zoning (Fig. 11(e)). A third type was observed in one phenocryst, showing gradual normal zoning (Fig. 11(d)). Both types were observed in phenocrysts in Showa-Iwojima mafic inclusions. Some phenocrysts have a large variation in $\mathrm{Al}_{2} \mathrm{O}_{3}, \mathrm{TiO}_{2}$ and $\mathrm{Cr}_{2} \mathrm{O}_{3}$ contents from core to rim despite a relatively small change in $\mathrm{Mg \#} \mathrm{(Figs.} \mathrm{11(a),}$ (b) and (d)). High $\mathrm{Al}_{2} \mathrm{O}_{3}$ contents of clinopyroxene phenocryst cores and large variations between core and rim were also described in mafic inclusions in Chaos Crags lavas in Lassen Volcanic National Park, California, by Heiken and Eichelberger (1980). The variations in $\mathrm{Al}_{2} \mathrm{O}_{3}$ content in 

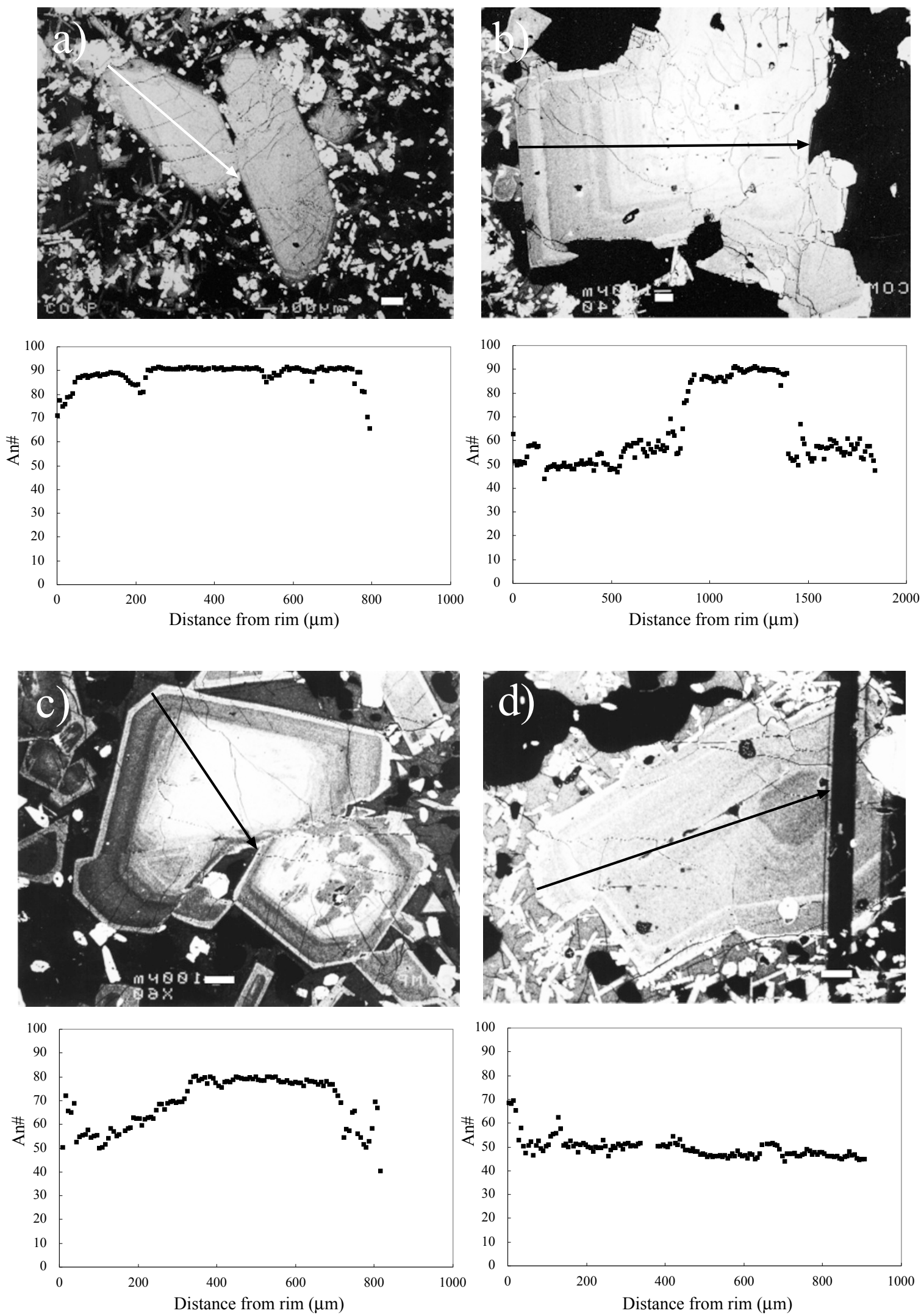

Fig. 6. Photomicrographs (back-scattered electron images; BEI) and zoning profiles of plagioclase phenocrysts of Showa-Iwojima mafic inclusions. Numbers on $y$ axes are $\mathrm{An} \#(=\mathrm{Ca} /(\mathrm{Ca}+\mathrm{Na}) \times 100 \%)$. The lines with arrows in the photomicrographs correspond to the line scans. a) Plagioclase having An-rich core (An\#89.8) with flat zoning profile. b) Plagioclase having An-rich core and sodic rim. c) Plagioclase having An-rich core (An\#82.6) with normal zoning in the inner part and reverse zoning in the rim. d) Plagioclase having Ab-rich core (An\#46.9) with a flat zoning profile in the inner part and reverse zoning at the rim. e) Plagioclase having Ab-rich core (An\#47.9) with oscillatory zoning profile and wide calcic band (An\#60.8) in the inner part. f) Plagioclase with an oscillatory zoning profile and wide calcic band (An\#63.3) in the inner part. g) Plagioclase having core of An\#71.3 with normal zoning in the inner part and dusty zone along the boundary between the inner part and rim. h) Plagioclase having core of An\#68.0 with normal zoning in the inner part and reverse zoning at the rim. 

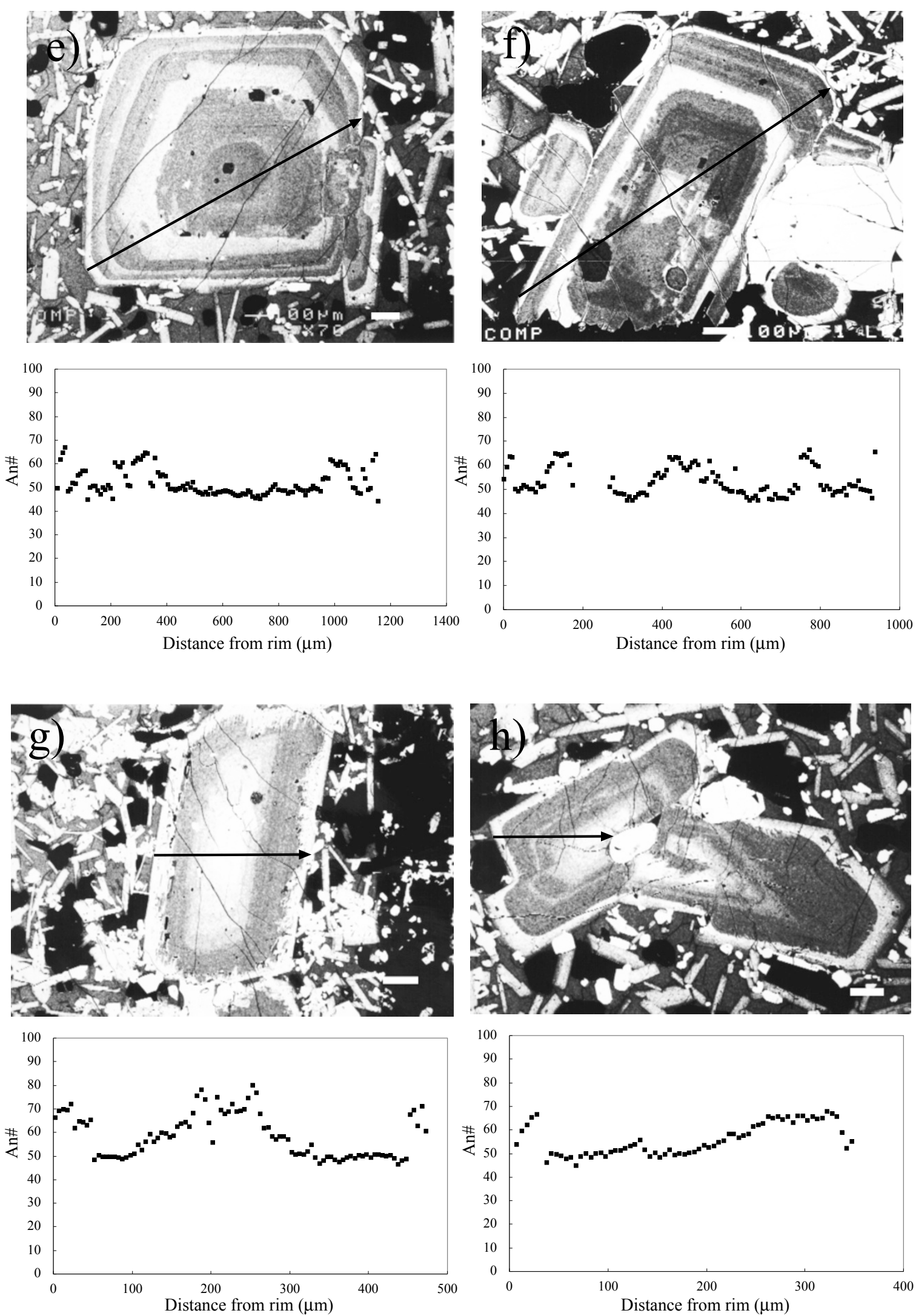

Fig. 6. (continued). 

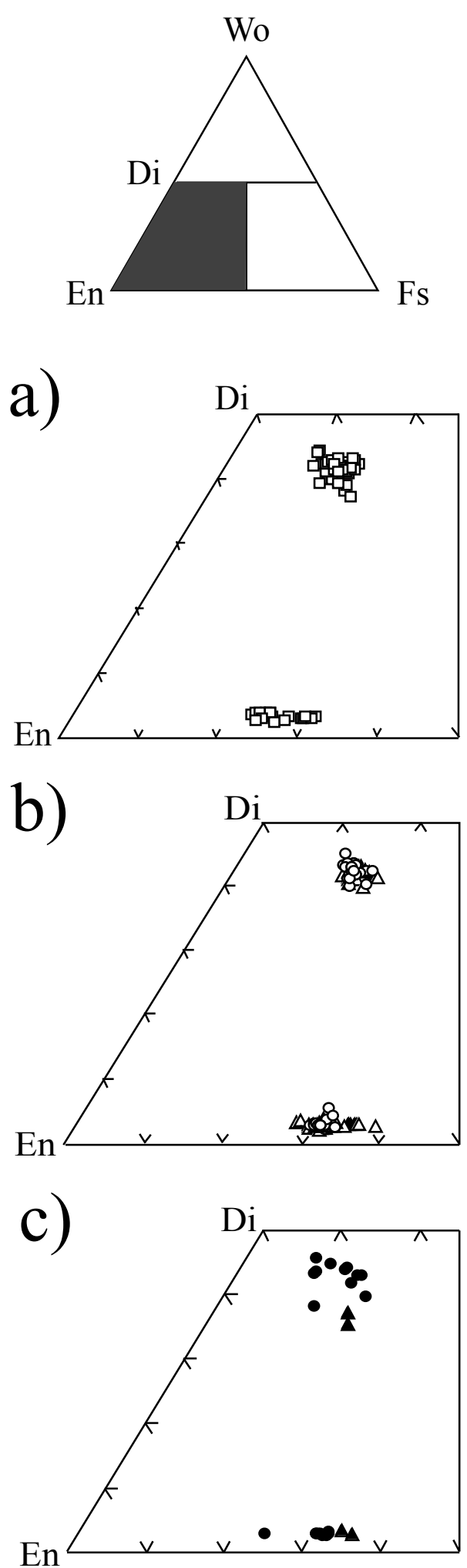

Fig. 7. Compositions of pyroxene phenocryst cores in the post-caldera basalt, rhyolites and mafic inclusions from Satsuma-Iwojima volcano. a) Inamuradake basalt, b) Iwodake (triangles) and Showa-Iwojima (circles) rhyolites and c) Iwodake (triangles) and Showa-Iwojima (circles) mafic inclusions. clinopyroxene phenocrysts were also larger than in those of Inamuradake scoria and Showa-Iwojima rhyolite (Fig. 12). In addition, the $\mathrm{Al}_{2} \mathrm{O}_{3}$ content seems to correlate with $\mathrm{TiO}_{2}$ and/or $\mathrm{Cr}_{2} \mathrm{O}_{3}$ contents (Figs. 11(a), (b), (c) and (d)) and the $\mathrm{Al}_{2} \mathrm{O}_{3}, \mathrm{TiO}_{2}$, and $\mathrm{Cr}_{2} \mathrm{O}_{3}$ contents fluctuate from core to rim (Figs. 11(a), (b) and (d)).

The orthopyroxene phenocrysts analyzed have flat zoning in their inner parts and reverse zoning at their rims (Figs. 11(f) and (g)), except for one sample. One orthopyroxene phenocryst in the Showa-Iwojima mafic inclusion (SM-2) has the opposite zoning profile, showing flat zoning in its inner part and normal zoning at the rim (Fig. 11(h)). This orthopyroxene obviously originated from basaltic magma because its core contains Mg-rich olivine (Mg\#90) and An-rich (An\#90) plagioclase inclusions.

\subsection{Temperature and oxygen fugacity estimates of Iwodake and Showa-Iwojima rhyolites and Inamu- radake basalt}

Two-pyroxene thermometry (Lindsley, 1983) was applied to the compositions of intergrown pyroxene phenocrysts in the Iwodake bombs and Showa-Iwojima lava. The compositions used for the calculations, Wo $\mathrm{W}_{4-44} \mathrm{En}_{41-43} \mathrm{Fs}_{14-16}$, $\mathrm{Mg} \# 72-75$ and $\mathrm{Al}_{2} \mathrm{O}_{3}=1.0-1.8 \mathrm{wt} \%$ for clinopyroxene and $\mathrm{Wo}_{2-3} \mathrm{En}_{62-66} \mathrm{Fs}_{31-35}, \mathrm{Mg} \# 64-68$ and $\mathrm{Al}_{2} \mathrm{O}_{3}=0.4-$ $1.1 \mathrm{wt} \%$ for orthopyroxene, are typical phenocryst cores of the rhyolites (Figs. 7-9). The thermometry indicates that magma temperatures were $960 \pm 28(1 \sigma, n=5)^{\circ} \mathrm{C}$ for the Iwodake rhyolite and $967 \pm 29(1 \sigma, n=6)^{\circ} \mathrm{C}$ for the Showa-Iwojima rhyolite, respectively. Crystallization temperatures of intergrown pyroxenes in Inamuradake scoria, whose compositions are $\mathrm{Wo}_{39-41} \mathrm{En}_{44-47} \mathrm{Fs}_{13-16}$, Mg\#7178 and $\mathrm{Al}_{2} \mathrm{O}_{3}=2.1-2.9 \mathrm{wt} \%$ for clinopyroxene and $\mathrm{Wo}_{4}$ $\mathrm{En}_{70-75} \mathrm{Fs}_{21-27}, \mathrm{Mg} \# 72-79$ and $\mathrm{Al}_{2} \mathrm{O}_{3}=1.3-1.7 \mathrm{wt} \%$ for orthopyroxene (Figs. 7-9), are $1125 \pm 27(1 \sigma, n=11)^{\circ} \mathrm{C}$.

Coexisting FeTi-oxide pairs from the Iwodake and Showa-Iwojima rhyolite were also analyzed. Temperatures and oxygen fugacity estimated using QUILF are $942 \pm 50$ $(1 \sigma, n=9)^{\circ} \mathrm{C}$ and $-10.2 \pm 1.0 \log$ units $(1.0 \pm 1.0 \log$ units above NNO buffer) for the Iwodake bomb and pumice and $880 \pm 24(1 \sigma, n=12)^{\circ} \mathrm{C}$ and $-10.8 \pm 0.4 \log$ units $(1.6 \pm 0.4 \log$ units above NNO buffer) for the ShowaIwojima lava, respectively. The temperature estimates for Showa-Iwojima rhyolite are somewhat lower than those of Ueda and Itaya (1981), which ranged from 948 to $959^{\circ} \mathrm{C}$ and -12.3 to $-12.1 \log$ units (1.2 log unit below NNO buffer). They also estimated temperature and oxygen fugacity of the Iwodake rhyolitic lava at 814 to $829^{\circ} \mathrm{C}$ and -15.7 to -15.2 $\log$ units (1.7 to $1.8 \log$ units below NNO buffer).

The temperature of the Iwodake rhyolite estimated by two-pyroxene thermometry $\left(960 \pm 28^{\circ} \mathrm{C}\right)$ is similar to that estimated by FeTi-oxide pairs $\left(942 \pm 50^{\circ} \mathrm{C}\right)$. This similarity indicates that the magma temperature of the Iwodake rhyolite was $940-960^{\circ} \mathrm{C}$. On the other hand, the temperature of the Showa-Iwojima rhyolite estimated by FeTi-oxide pairs $\left(880 \pm 24^{\circ} \mathrm{C}\right)$ is somewhat lower than that estimated by twopyroxene thermometry $\left(967 \pm 29^{\circ} \mathrm{C}\right)$ and the estimates by FeTi-oxide pairs of Ueda and Itaya (1981). Fumaroles in the Iwodake summit crater reach temperatures up to $900^{\circ} \mathrm{C}$ (Shinohara et al., 2002) and the magmatic gas discharging from the crater is thought to be derived from the Showa- 

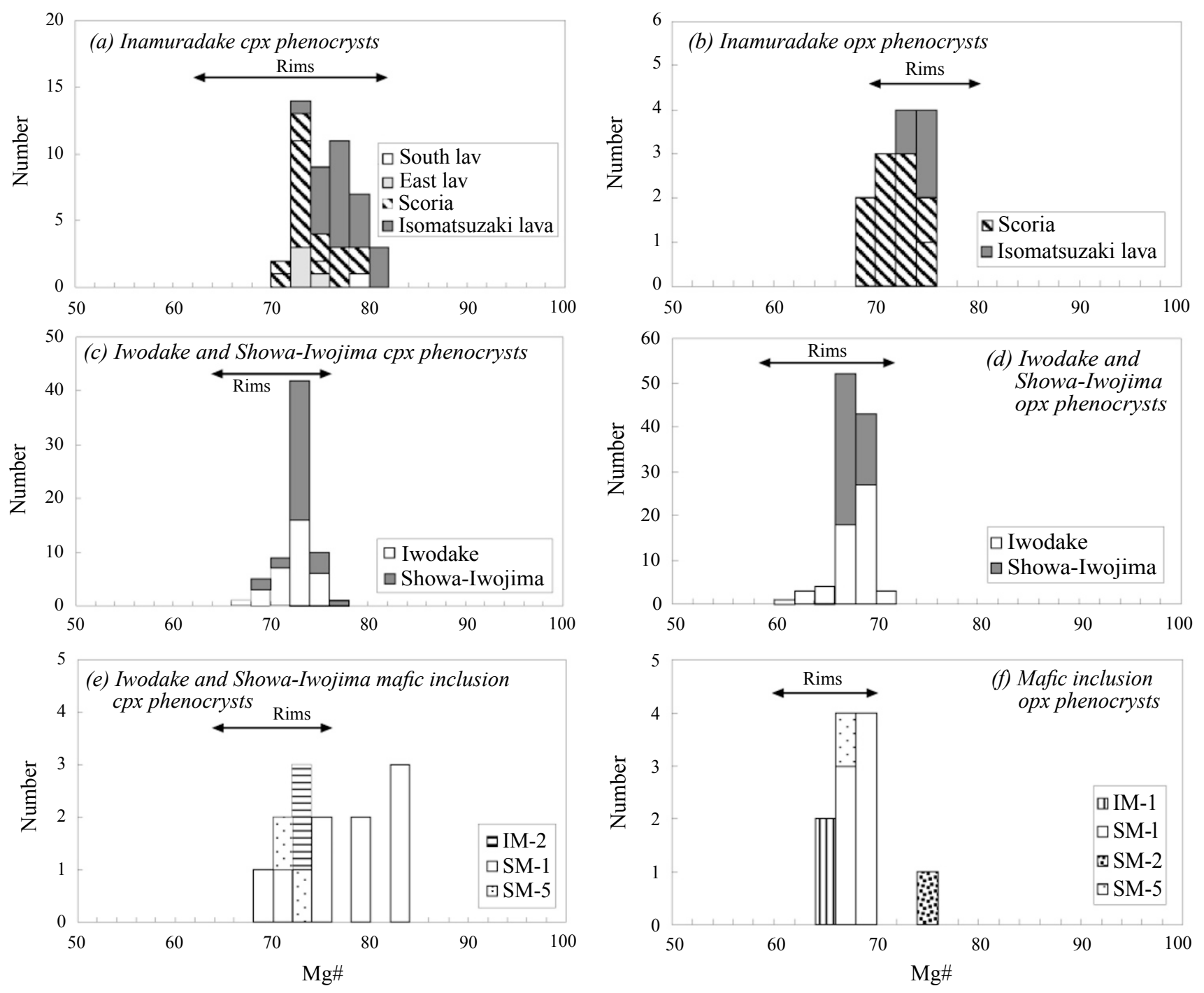

Fig. 8. Composition of pyroxene phenocryst cores and rims in the post-caldera basalt, rhyolites and mafic inclusions from Satsuma-Iwojima volcano. $\mathrm{Mg} \#=\mathrm{Mg} /(\mathrm{Mg}+\mathrm{Fe}) \times 100 \%$. a) Clinopyroxene of Inamuradake eruptions, b) orthopyroxene of Inamuradake eruptions, c) clinopyroxene of Iwodake and Showa-Iwojima rhyolites, d) orthopyroxene of Iwodake and Showa-Iwojima rhyolites, e) clinopyroxene of Iwodake and Showa-Iwojima mafic inclusions and f) orthopyroxene of Iwodake and Showa-Iwojima mafic inclusions.

Iwojima rhyolitic magma (Saito et al., 2001; Kazahaya et $a l .$, 2002). This is consistent with the magma temperature of the Showa-Iwojima rhyolite being more than $900^{\circ} \mathrm{C}$. The lower estimate by FeTi-oxide pairs may have been affected by post-emplacement re-equilibration. Taken together, however, the FeTi-oxide temperatures suggest that the pyroxene temperatures should be taken as maximum estimates.

\section{Discussion}

\subsection{Source of mafic inclusions in Iwodake rhyolite}

Mafic inclusions from Iwodake rhyolite contain a composition similar or slightly more silicic than the Inamuradake basalt (Figs. 3 and 4). Moreover, the major element compositions of the inclusions plot between those of Inamuradake scoria and scoria groundmass (Fig. 3). These results are consistent with a magma similar to Inamuradake basaltic magma being the source of the mafic inclusions, but that some fractional crystallization of the basaltic magma might have occurred before it was entrained in the Iwodake magma. This is consistent with the spatial and temporal association and overlapping periods of activity for Iwodake and Inamuradake.

Slightly more $\mathrm{SiO}_{2}$-rich compositions of inclusions might also be a result of mixing of the mafic end member with rhyolitic magma prior to complete solidification. The presence of inherited plagioclase phenocrysts with Ab-rich cores (Fig. 5) and orthopyroxene phenocrysts with Fe-rich cores (Figs. 7 and 8) in Iwodake mafic inclusions provides some evidence for such mixing. Two clinopyroxene phenocrysts in IM-2 show higher $\mathrm{Al}_{2} \mathrm{O}_{3}$ contents than those of Inamuradake basalts and the Iwodake rhyolites (Fig. 9). This could be caused by a drastic decrease in temperature at the time of contact of the basalt with the rhyolite, as expected from results of crystallization experiments on basalt (Kouchi et al., 1986) and melts of the system $\mathrm{CaMgSi}_{2} \mathrm{O}_{6}$ $\mathrm{CaAl}_{2} \mathrm{Si}_{2} \mathrm{O}_{8}$ (Tsuchiyama, 1985a). Major and trace ele- 

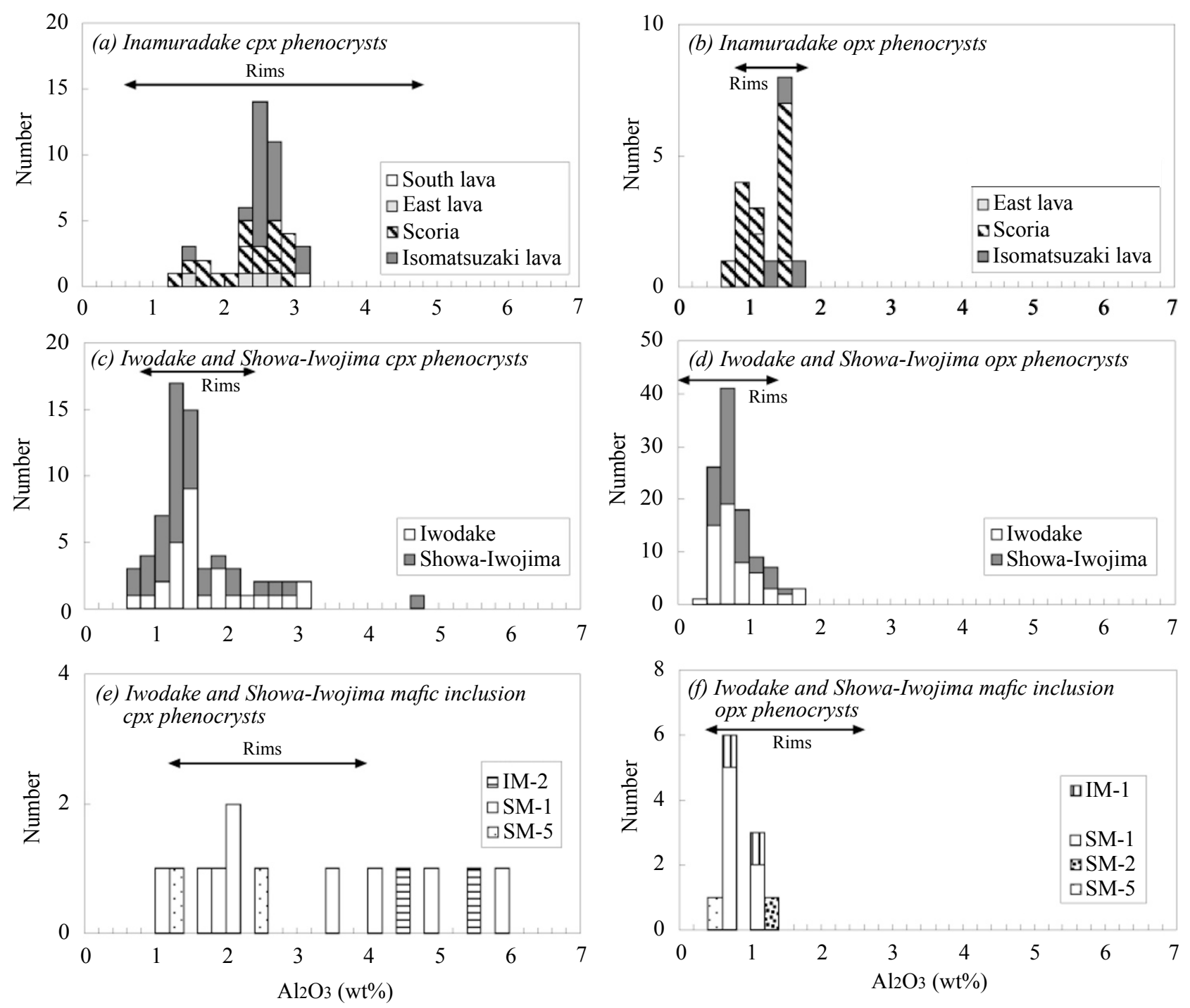

Fig. 9. $\mathrm{Al}_{2} \mathrm{O}_{3}$ contents of pyroxene phenocryst cores and rims in the post-caldera basalt, rhyolites and mafic inclusions from Satsuma-Iwojima volcano. a) Clinopyroxene of Inamuradake eruptions, b) orthopyroxene of Inamuradake eruptions, c) clinopyroxene of Iwodake and Showa-Iwojima rhyolites, d) orthopyroxene of Iwodake and Showa-Iwojima rhyolites, e) clinopyroxene of Iwodake and Showa-Iwojima mafic inclusions and f) orthopyroxene of Iwodake and Showa-Iwojima mafic inclusions.

ment compositions of the Iwodake rhyolite show mixing trends between the Inamuradake basalt and rhyolite (Figs. 3 and 4), indicating an input of the basaltic magma into the host rhyolite. However, significantly fewer plagioclase phenocrysts with Ab-rich cores occur in Iwodake mafic inclusions than in Showa-Iwojima mafic inclusions (Fig. 5), indicating comparatively minor mafic-felsic magma interaction for Iwodake. Most plagioclase and pyroxene phenocrysts in the Iwodake mafic inclusions have unzoned cores, and changes in composition of their rims are consistent with mixing just prior to eruption (see Figs. 6(a) and 11(f)).

5.2 Source of mafic inclusions in Showa-Iwojima rhyolite

Major element compositions of Showa-Iwojima mafic inclusions lie along mixing trends between Inamuradake magmas and the Showa-Iwojima rhyolite (Fig. 3). The less evolved Inamuradake magma (East lava; NE in Fig. 3) or an intermediate composition between Inamuradake scoria (Nsc) and its groundmass (Ngm) can be estimated as the basaltic end members. The most silicic Showa-Iwojima rhyolite (S-2) is taken as the rhyolitic end member. Mixing trends of trace element compositions of the ShowaIwojima mafic inclusions (Fig. 4) are consistent with the above hypothesis. Major and trace element compositions of the Showa-Iwojima rhyolite also form mixing trends between the Inamuradake basalt and rhyolite (Figs. 3 and 4), pointing to input of basaltic magma into the host rhyolite. The large variations in the plagioclase and pyroxene core compositions of the mafic inclusions (Figs. 5, 7 and 8) indicate that these phenocrysts were derived from both rhyolitic and basaltic precursor magmas. The core compositions of An\#60-80 of plagioclase phenocrysts in the Showa-Iwojima mafic inclusions overlap those of An-poor plagioclase phenocrysts in the Inamuradake basalt (An\#70-80) and those of the plagioclase microphenocrysts in the mafic inclusions (Fig. 5). These phenocrysts likely began crystallizing in the Inamuradake basalt or a hybrid magma formed by mixing of some basalt and rhyolite. 

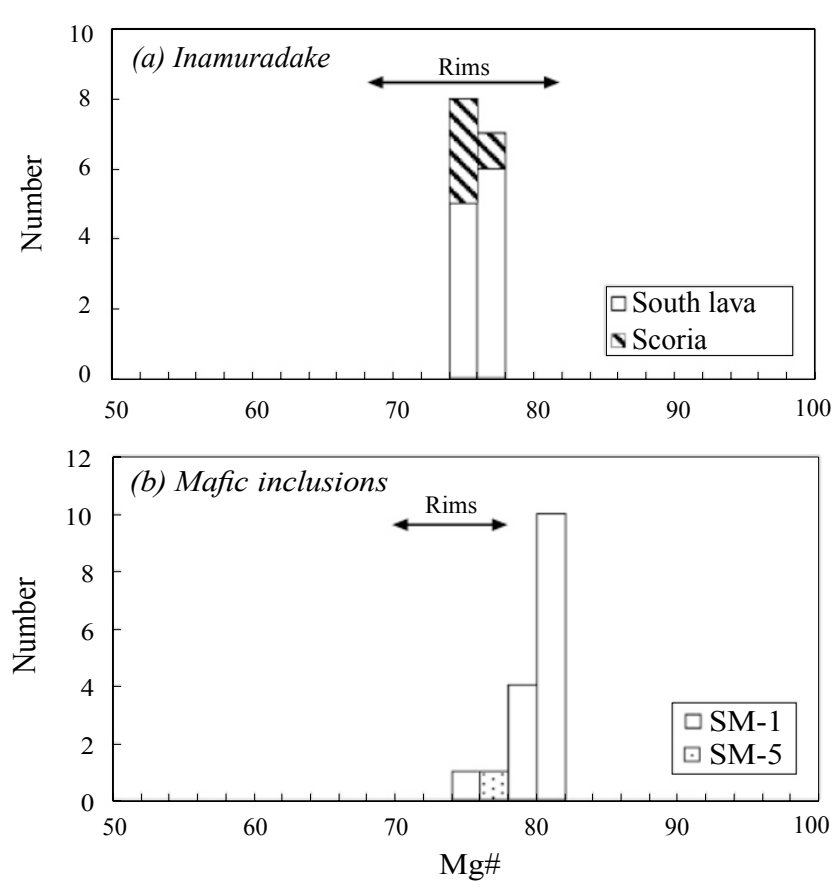

Fig. 10. Composition of olivine phenocryst cores and rims in the post-caldera basalt and Showa-Iwojima mafic inclusions. $\mathrm{Mg} \#=\mathrm{Mg} /(\mathrm{Mg}+\mathrm{Fe}) \times 100 \%$. a) Inamuradake eruptions, and b) Showa-Iwojima mafic inclusions.

Olivine phenocrysts in the Showa-Iwojima mafic inclusions have slightly more $\mathrm{Mg}$-rich cores than those from Inamuradake basalt (Fig. 10). The maximum Mg\# of clinopyroxene phenocryst cores from inclusions is also higher than those from Inamuradake basalt. These results suggest that basaltic end member forming these inclusions was slightly more primitive than the Inamuradake basalt.

\subsection{Mixing process of basaltic magmas and Showa- Iwojima rhyolite}

Major element compositions of inclusions SM-1b and SM-4 plot along the mixing lines between the less evolved Inamuradake basalt (East lava; NE in Fig. 3) and the most silicic Showa-Iwojima rhyolite (S-2). However, major element compositions of inclusions SM-1a, SM-2 and SM3 form a second mixing trend between the rhyolite and a composition between the Inamuradake scoria (Nsc) and its groundmass (Ngm; Fig. 3). These mixing trends indicate that two or more basaltic compositions are represented in the mixing process. Two mixing processes can be considered in the magma chamber: (I) multiple, or semi-continuous inputs of basaltic magma (Fig. 13(b)), or (II) a single input of basaltic magma and formation of the large compositional variation within a mixed layer (Fig. 13(c)).

In model (I), distinct basaltic magmas repeatedly recharged the base of the rhyolitic magma chamber before the Showa-Iwojima eruption (Fig. 13(b)). One basaltic magma had the same or slightly less evolved composition than that of Inamuradake magma, whereas another had a composition intermediate between Inamuradake scoria and its groundmass, possibly formed by fractional crystallization involving the observed phenocryst assemblage. During each injection, mixing of basaltic magmas and Showa-Iwojima rhyolite oc- curred to form a thin hybrid andesitic layer. Heat loss and segregation of volatiles from the basalt to the overlying rhyolite caused crystallization and vesiculation of the magma, which may have produced a growing layer of mafic foam below the rhyolite (Eichelberger, 1980). Such a layer could accumulate as long as the bubbles were not re-entrained to the underlying convection regime.

Thomas et al. (1993) conducted analog experiments in which foams interacting with an overlying more viscous layer showed different behaviors. In one regime, bubbles move individually across the interface, entraining a small quantity of lower layer liquid and eventually the two layers progressively stir into a homogeneous mixture. In the second regime, bubbles formed a foam layer at the interface that eventually became gravitationally unstable and rose as plumes with a mixed composition. The transition between these regimes depends on the gas flux and the viscosity ratio between layers. A plume regime is predicted if the viscosity ratio is greater than 3-30.

Kazahaya et al. (2002) estimated the viscosity of ShowaIwojima rhyolite with water concentration of $1.4 \mathrm{wt} \%$ to be $10^{4.9} \mathrm{~Pa} \cdot \mathrm{s}$ at $1000^{\circ} \mathrm{C}$ by the method given by Persikov (1990). Assuming that the underlying basalt had a similar major element composition and water concentration (1.2$2.8 \mathrm{wt} \%$; Saito et al., 2001) to Inamuradake basalt, we calculate viscosities of the basalt at $1125^{\circ} \mathrm{C}$ to be $10^{2.5}$ and $10^{2.1}$ $\mathrm{Pa} \cdot \mathrm{s}$, at 1.2 and $2.8 \mathrm{wt} \%$ water, respectively. Therefore, the viscosity ratios between the Showa-Iwojima rhyolite and the underlying basalt can be estimated to be $230-630$, indicating the potential occurrence of a plume regime during intrusion of the basalt beneath the Showa-Iwojima rhyolite. We envision the formation of an intermediate layer whose instability and breakup formed the Showa-Iwojima mafic inclusions (cf. Eichelberger, 1980; Thomas et al., 1993; Clynne, 1999), and led to a high degree of mafic-felsic magma interaction and volatile transfer to the rhyolite. Under slightly different conditions, it is possible that small buoyant plumes consisting mainly of volatile-rich foam were entrained into the convecting rhyolite magmas. This latter process might explain the low abundance of very small inclusions such as seen at Iwodake and other occurrences (e.g., Stimac et al., 1990; Bacon, 1986).

In model (II), basaltic magma with a similar or less evolved composition than Inamuradake magma intruded the base of the rhyolite after the Iwodake eruptions, forming a hybrid andesitic layer (Fig. 13(c)). The injection and mixing process continued until the Showa-Iwojima eruption, resulting in formation of a relatively thick mixed layer. In the early stage of the process, heat and gas loss from the basalt to the rhyolite may have promoted fractional crystallization of the basalt. This produced magma with a composition intermediate between the Inamuradake scoria and its groundmass, thought to be the basaltic end member for SM-1a, 2 and 3 (Fig. 3). Mixing of the evolved basaltic magma and the rhyolite produced hybrid magmas represented by SM1a, SM-2 and SM-3. The inclusions might have separated from the mixed layer and were stirred into the host rhyolite as in model (I) (Clynne, 1999). In the lower mixed layer, injection of the less evolved basalt might continue. A significant compositional variation in the mixed layer could be 

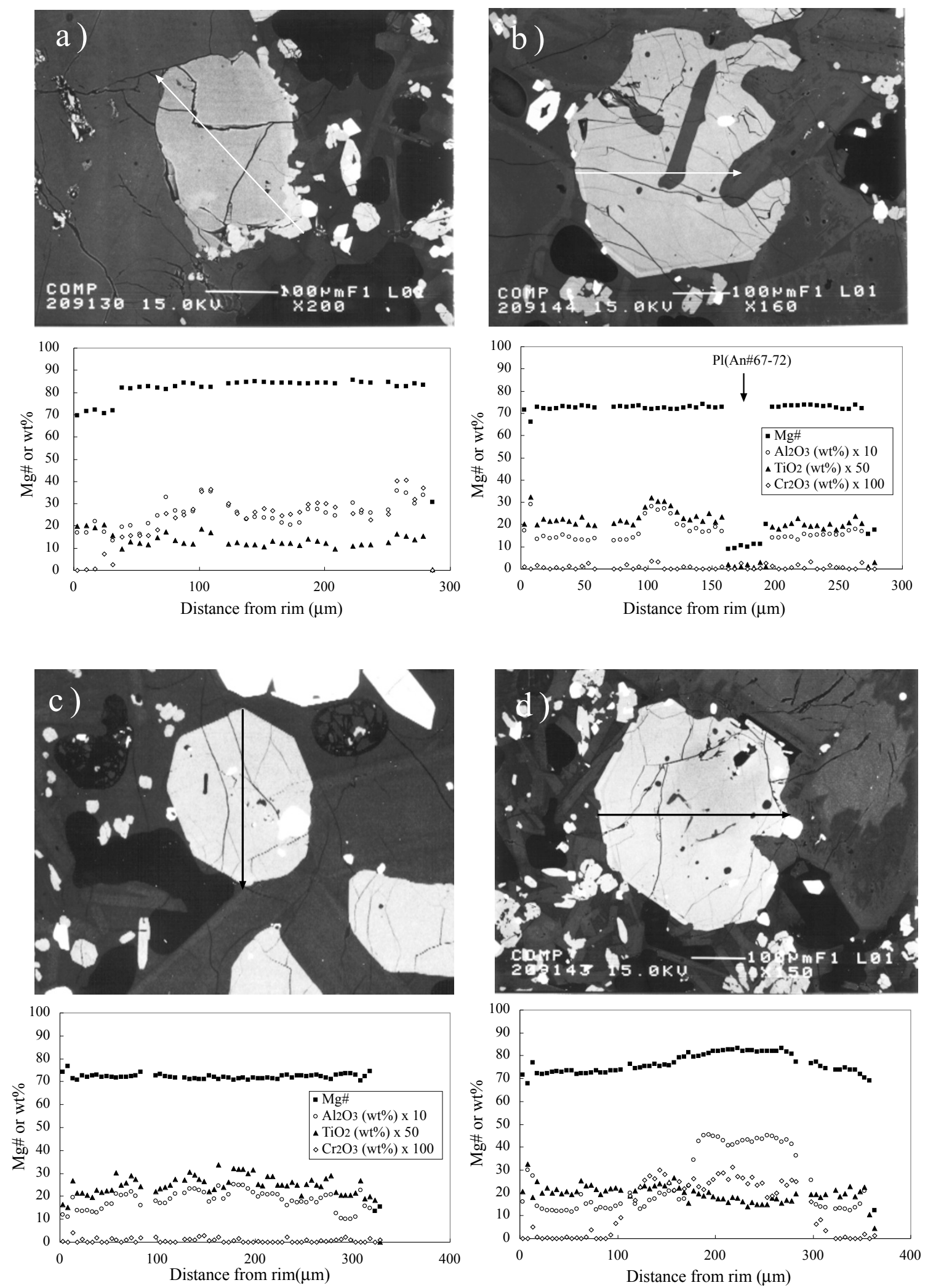

Fig. 11. Photomicrographs (back-scattered electron images; BEI) and zoning profiles of pyroxene phenocrysts in Iwodake and Showa-Iwojima mafic inclusions. Numbers on y axes are $\mathrm{Mg} \#(=\mathrm{Mg} /(\mathrm{Mg}+\mathrm{Fe}) \times 100 \%$, closed squares $)$ or concentrations of $\mathrm{Al}_{2} \mathrm{O}_{3}(\mathrm{wt} \% \times 10$, open circles), TiO (wt $\% \times 50$, closed triangles) and $\mathrm{Cr}_{2} \mathrm{O}_{3}(\mathrm{wt} \% \times 100$, open diamonds). The lines with arrows in the photomicrographs correspond to the line scans. a) Clinopyroxene having Mg-rich core with flat zoning profile from a Showa-Iwojima mafic inclusion (SM-1). b) Clinopyroxene with flat zoning profile from a Showa-Iwojima mafic inclusion (SM-1). c) Clinopyroxene with flat zoning in the inner part and reverse zoning in the rim from a Showa-Iwojima mafic inclusion (SM-5). d) Clinopyroxene with gradually Fe-rich from core to rim from a Showa-Iwojima mafic inclusion (SM-1). e) Clinopyroxene with gradually Mg-rich from core to rim from a Showa-Iwojima mafic inclusion (SM-1). f) Orthopyroxene with flat zoning in the inner part and reverse zoning in the rim from an Iwodake inclusion (IM-1). g) Orthopyroxene with flat zoning in the inner part and reverse zoning in the rim from a Showa-Iwojima mafic inclusion (SM-1). h) Orthopyroxene having Mg-rich core with flat zoning in the inner part and normal zoning in the rim from a Showa-Iwojima mafic inclusion (SM-2). The pyroxene has inclusions of olivine (Mg\#90) and plagioclase (An\#90) in the inner part. 

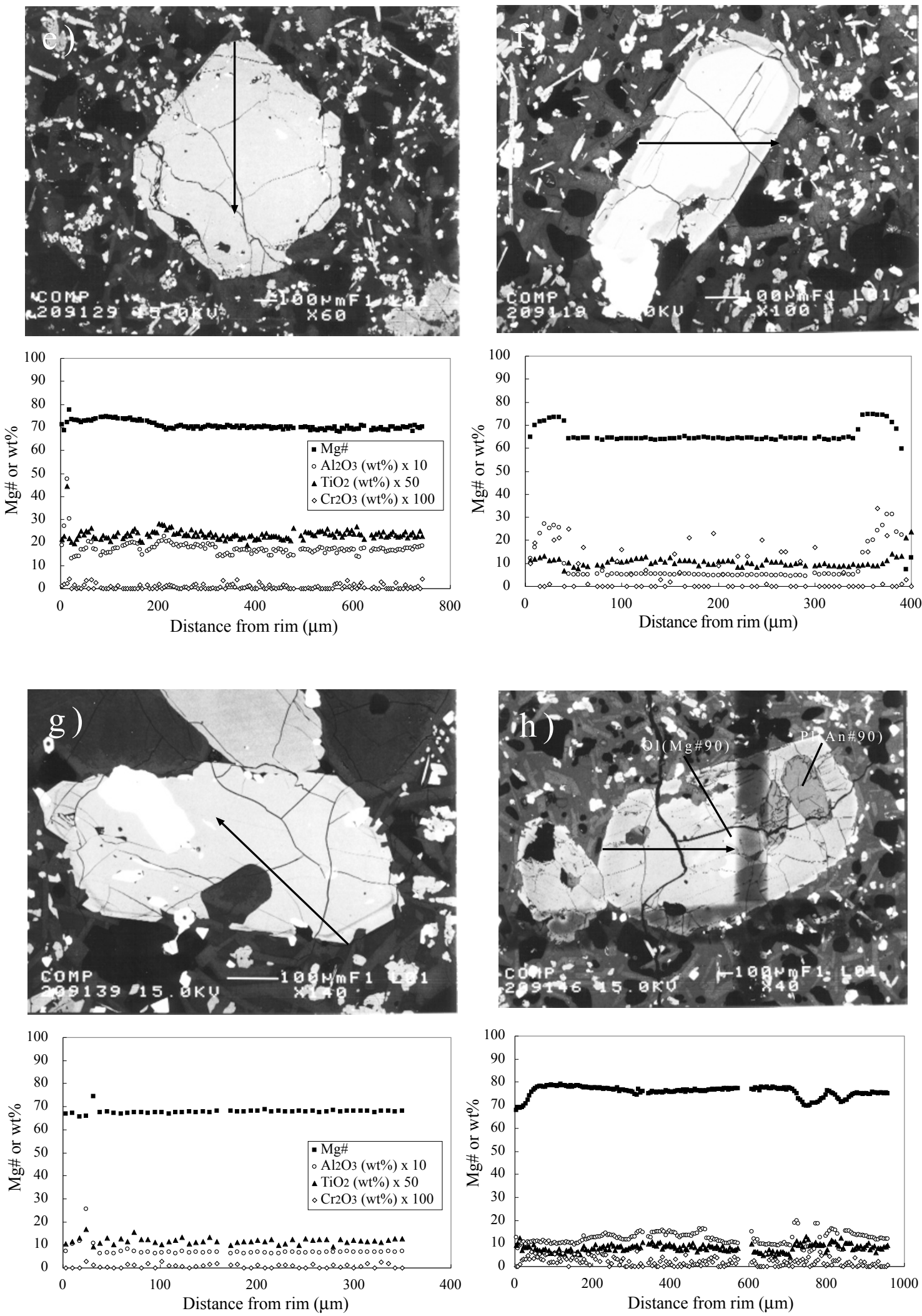

Fig. 11. (continued).

present depending on the mixing ratio of basalt to rhyolite and extent of fractional crystallization.

A thermal gradient must also have existed across the mixed layer due to heat loss to the cooler rhyolite. Any thermally driven convection in the layer would have led to stirring and hybridization (Kouchi and Sunagawa, 1985; Tepley et al., 1999). Magma in the upper mixed layer may have descended and mingled with the less evolved basalt in the lower mixed layer. The magmas represented by SM-1b and SM-4 could have formed by mixing between the hy- 

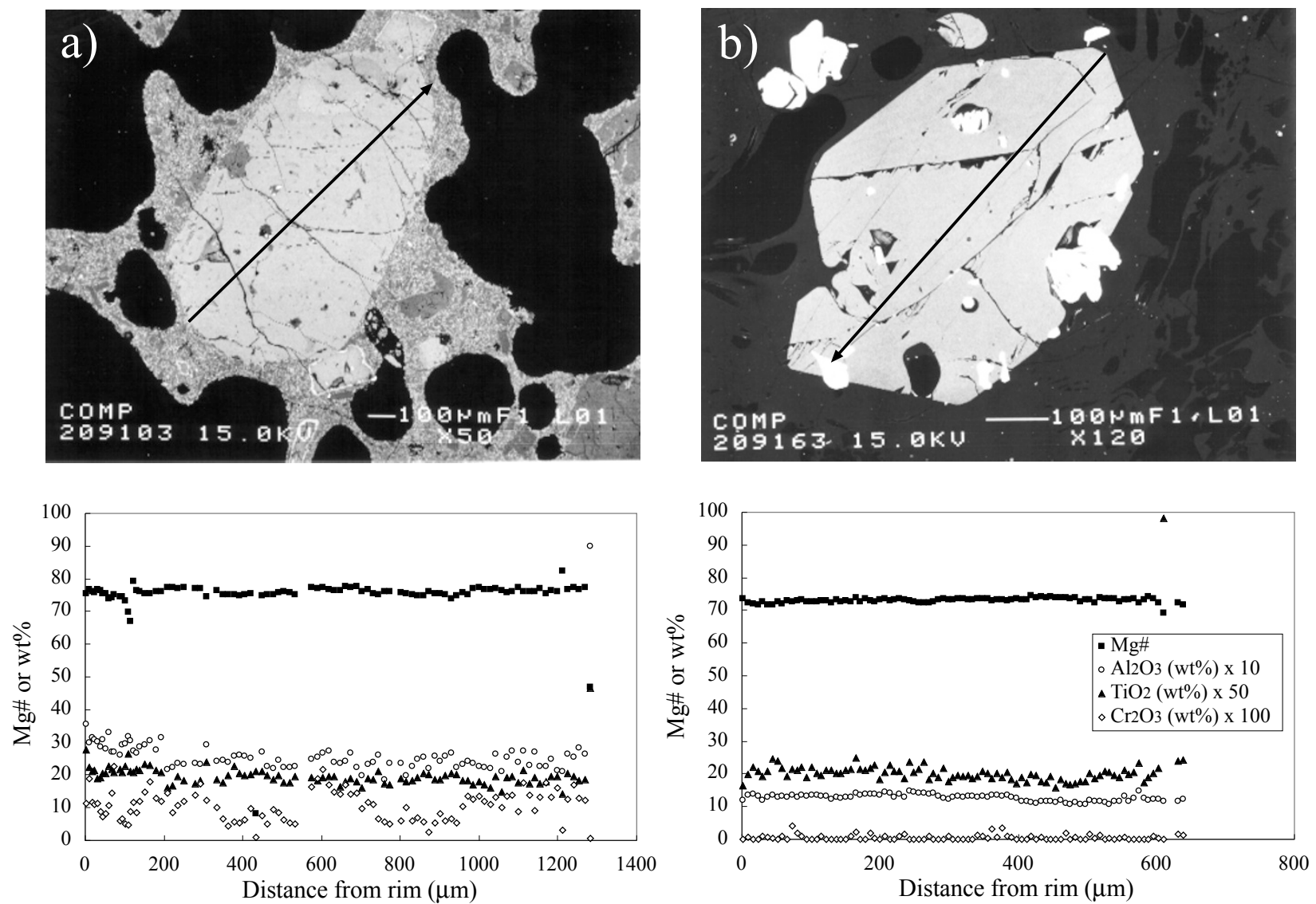

Fig. 12. Photomicrographs (back-scattered electron images; BEI) and zoning profiles of clinopyroxene phenocrysts in a) Inamuradake scoria and b) Showa-Iwojima rhyolitic lava. Numbers on y axes are $\mathrm{Mg} \#\left(=\mathrm{Mg} /(\mathrm{Mg}+\mathrm{Fe}) \times 100 \%\right.$, closed squares) or concentrations of $\mathrm{Al}_{2} \mathrm{O}_{3}($ wt $\% \times 10$, open circles), $\mathrm{TiO}_{2}(\mathrm{wt} \% \times 50$, closed triangles $)$ and $\mathrm{Cr}_{2} \mathrm{O}_{3}(\mathrm{wt} \% \times 100$, open diamonds). The lines with arrows in the photomicrographs correspond to the line scans.

brid magma in the upper mixed layer, represented by inclusions of SM-1a and SM-2 (Fig. 3), and the less evolved basaltic magma in the lower part of the mixed layer. During the Showa-Iwojima eruption, the compositionally varied andesitic magma in the mixed layer was withdrawn along with the rhyolite to form Showa-Iwojima mafic inclusions (e.g., Blake and Ivey, 1986; Koyaguchi, 1986a).

Some observations about Showa-Iwojima mafic inclusions indicate that model (II) is more likely. First, one Showa-Iwojima mafic inclusion, represented by samples SM-1a and SM-1b (Table 2 and Fig. 3), reveals a large internal variation in composition. This variation suggests the existence of two basaltic end members in the mixed layer, which is consistent with the compositional variation in the mixed layer as expected in model (II). Second, transport of plagioclase from the upper more silicic part to the lower more mafic part by magma convection (Fig. 13) could explain the various zoning patterns shown in Fig. 6. Plagioclase phenocrysts in the Showa-Iwojima mafic inclusions show gradual normal zoning or drastic changes of the chemical composition (Figs. 6(b) and (c)) from core to rim, indicating that plagioclase generated in basaltic magma subsequently resided in andesitic or rhyolitic magma. The oscillatory zoning with multiple An-rich bands (An\# 70) of plagioclase phenocrysts (Fig. 6(f)) may have been caused by crystallization in a melt with a variable chemical compo- sition, such as that of the mixed layer. Third, large variations and fluctuations in $\mathrm{Al}_{2} \mathrm{O}_{3}, \mathrm{TiO}_{2}$ and $\mathrm{Cr}_{2} \mathrm{O}_{3}$ contents from core to rim in single clinopyroxene phenocrysts in Showa-Iwojima mafic inclusions (Figs. 11(a), (b), (c) and (d)) indicate that they crystallized from variable melt compositions or at highly variable cooling rates (Tsuchiyama, 1985a; Kouchi et al., 1986; Feeley and Dungan, 1996). This is consistent with growth in a mixed layer where both compositional and thermal gradients are present. Fourth, the more common occurrence of mafic inclusions in the ShowaIwojima rhyolite compared to the Iwodake rhyolite suggests the presence of a thicker mixed layer.

Model (II) requires that hybridization of basaltic and rhyolitic magmas occurred in various proportions, with the mafic end member comprising more than $50 \%$ of the mixture based on the variation in whole-rock compositions (Figs. 3 and 4). This hybridization can only occur when both magmas behave as liquids after the magmas are mingled and in thermal equilibration (Sparks and Marshall, 1986). Sparks and Marshall (1986) demonstrate that complete hybridization depends on the initial temperatures of the magmas and the proportion of mafic magma in the mixture. We evaluated whether such hybridization in model (II) could occur based on thermal and compositional constraints on magma mixing. Model calculations for mixing between basaltic magma with an initial temperature of $1100^{\circ} \mathrm{C}$ and a 
(a) Formation of Iwodake mafic inclusions

Just before Iwodake eruptions

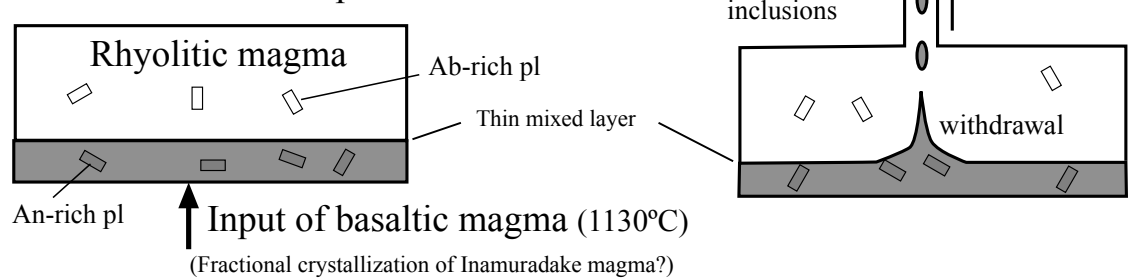

(b) Formation of Showa-Iwojima mafic inclusions (I) : Multiple inputs of basalts

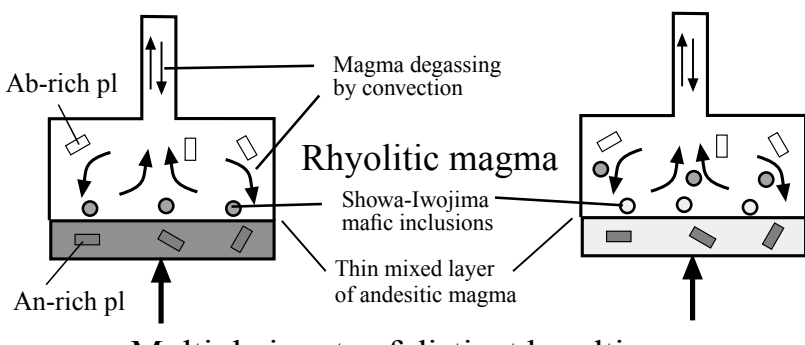

Showa-Iwojima eruption

Multiple inputs of distinct basaltic magmas since $1300 \mathrm{y}$. B. P.

(c) Formation of Showa-Iwojima mafic inclusions (II) : Single input of basalt

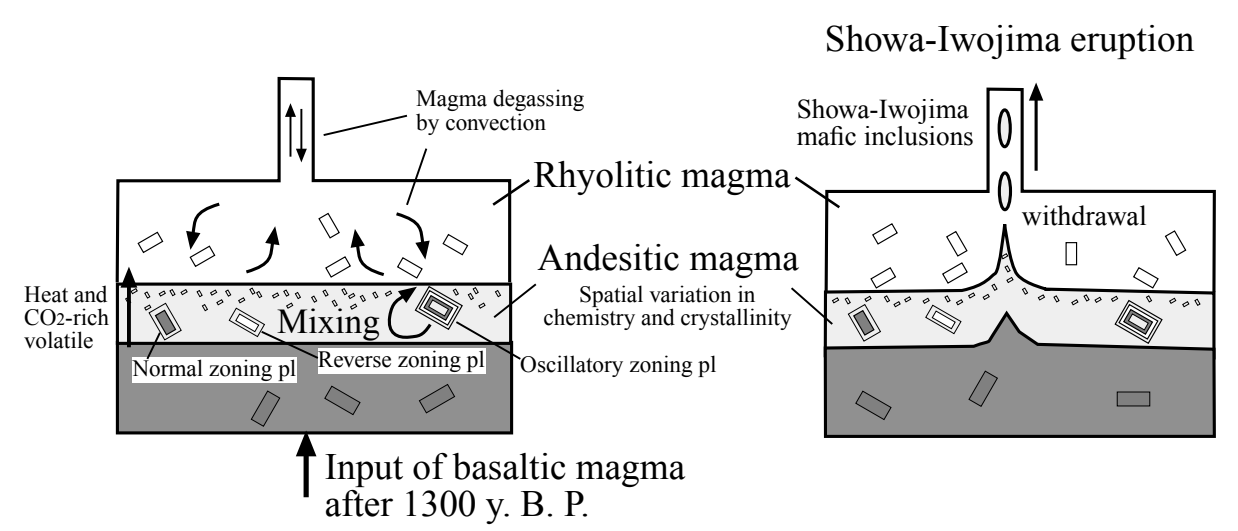

Fig. 13. Diagrams showing our conceptual models for mafic-felsic interactions in the Satsuma-Iwojima magma chamber during the post-caldera stages: a) Just before the Iwodake eruptions, basaltic magma having a similar chemical composition to Inamuradake magma intruded into the base of the rhyolitic magma chamber. During the Iwodake eruptions, the basaltic magma or the magma from the thin mixed layer was entrained by the Iwodake rhyolitic magma to form the Iwodake mafic inclusions. b) After 1300 y.B.P., basaltic magmas having different compositions intruded into the base of the rhyolitic chamber at least twice. During each injection, the basaltic and rhyolitic magmas mixed and formed mafic inclusions. The inclusions were stirred into the rhyolitic chamber. When Showa-Iwojima erupted, the various inclusions were emitted with the rhyolite. c) An alternative model for Showa-Iwojima mafic inclusions. Basaltic magma with composition similar to less evolved Inamuradake magma intruded into the base of the rhyolitic magma chamber. Mixing of the basalt and rhyolite proceeded to form an intermediate layer of andesitic magma until the Showa-Iwojima eruption (1934-1935). During the Showa-Iwojima eruption, the andesitic magma was entrained by the rhyolitic magma to form the Showa-Iwojima mafic inclusions. The inclusions have various chemical compositions because the layer has spatial variations in chemistry and crystallinity. pl = plagioclase.

water content of $0.58 \mathrm{wt} \%$, a similar temperature but lower water content than that of Inamuradake magma $\left(1125^{\circ} \mathrm{C}\right.$ and 1.2-2.8 wt\%; Saito et al., 2001), and a dry rhyolitic magma with an initial temperature of $950^{\circ} \mathrm{C}$, a similar temperature but lower water content than that of the Showa-Iwojima rhyolite (880-970 ${ }^{\circ} \mathrm{C}$ and $0.7-1.4 \mathrm{wt} \%$; Saito et al., 2001), show that the mafic magma will behave as a liquid at any proportions of mafic magma (figure 9 in Sparks and Marshall, 1986). Other calculations for mixing between the same basalt and rhyolite of $850^{\circ} \mathrm{C}$ and a water content of $1.77 \mathrm{wt} \%$ show that the mafic magma behaves as a liquid if its proportion is greater than 0.1 . As water depresses the viscosity of magma, the actual Inamuradake magma with a water content of $1.2-2.8 \mathrm{wt} \%$ should be less viscous than the magma composition in the model of Sparks and Marshall (1986). This indicates that hybridization at Satsuma-Iwojima will occur even more easily than indicated in the above calculations. The above estimation suggests that hybridization with mix- 
ing ratios in the mixed layer required by model (II) may have occurred at Satsuma-Iwojima volcano.

\subsection{Evolution of the post-caldera magma chamber}

A model of post-caldera magma evolution of the Satsuma-Iwojima system is proposed on the basis of petrological observations and chemical analyses of mafic inclusions in the rhyolites, as well as other geological and petrological evidence as discussed below.

Just before the latest caldera-forming eruption (6500 y.B.P.), rhyolitic magma was present at a depth of 3-7 km, based on melt inclusion volatile contents (Saito et al., 2001). The Iwodake eruptive episode began just after the calderaforming eruption and continued until 500 y.B.P. (Kawanabe and Saito, 2002), whereas Inamuradake activity occurred at about 3000 y.B.P. Contemporaneous eruption of basaltic and rhyolitic magmas in a small area, possibly along a single post-caldera fracture zone (Fig. 1), indicates coexistence of both magma reservoirs beneath the volcano during the postcaldera stage. The depth of the Iwodake rhyolite and Inamuradake basaltic magma reservoirs was estimated at about 3 and $3-5 \mathrm{~km}$, respectively, based on water and $\mathrm{CO}_{2}$ contents of melt inclusions in the Iwodake pumice and Inamuradake scoria (Saito et al., 2001). The very high eruption temperature of the rhyolites is also consistent with evolution of the rhyolite in the presence of basalt.

Mafic inclusions in rhyolites described in this study indicate that the underlying basaltic magma was intermittently or continuously in contact with the upper rhyolitic magma in the magma chamber (Fig. 13). The Iwodake mafic inclusions present in bombs produced by eruptions from 6500 to $\sim 3000$ y.B.P. suggest that such mafic-felsic interaction occurred since the time of the earlier Iwodake eruption. The presence of Ab-rich plagioclase (Fig. 5) and Fe-rich orthopyroxene (Fig. 8) in Iwodake mafic inclusions indicates that injection of Iwodake rhyolitic magma into the basaltic magma might have occurred at the contact surface to form a thin mixed layer, although the ratio of rhyolite to basalt would be very small. During the Iwodake eruptions, magma from the upper part of the basaltic layer or from the thin mixed layer may have been entrained by the volumetrically dominant rhyolite to form the partially quenched mafic inclusions in the Iwodake rhyolites (e.g., Blake and Ivey, 1986; Koyaguchi, 1986a; Feeley and Dungan, 1996; Fig. 13). These eruptions may have occurred just after the contact and mixing process, as suggested by the basaltic composition and the low abundance of the inclusions, which indicates that significant mixing did not proceed before each eruption.

In the time period from 1300 y.B.P. to the Showa-Iwojima eruption (1934-1935), a single injection of basaltic magma with a composition similar to less evolved Inamuradake magma, or multiple injections of basaltic magma with very similar composition, occurred at the base of the rhyolitic chamber (Fig. 13). This produced an intermediate layer between the upper rhyolite and the lower basalt chambers. The large variations in whole-rock chemistry (Figs. 3 and 4) and mineral chemistry (Figs. 5, 7 and 8) of the Showa-Iwojima mafic inclusions and their common occurrence in the host rhyolite suggest that significant compositional variation existed in the mixed layer. Major element compositions of the Showa-Iwojima rhyolites show a mixing trend between the Inamuradake groundmass and the most evolved ShowaIwojima rhyolite (S-2 in Fig. 3). This may have been caused by disaggregation of the inclusions and mingling of this material into the rhyolitic host (Stimac and Pearce, 1992; Tepley et al., 1999), or mixing at the boundary between the mixed layer and the rhyolitic layer before or during the Showa-Iwojima eruption.

Satsuma-Iwojima volcano has released a large amount of magmatic gas from the summit crater of Iwodake at least over the past 800 years. Kazahaya et al. (2002) summarized volcanic gas flux observations and melt inclusion analyses (Saito et al., 2001) and concluded that this long-term release of the magmatic gas could be caused by degassing of the rhyolitic magma by convection in a conduit. They also concluded that the $\mathrm{CO}_{2}$-rich volatile components were most likely supplied to the rhyolite from an underlying basaltic magma. The stratified magma chamber model, which is predicted from petrologic observations of Showa-Iwojima rhyolite and the mafic inclusions, may provide an explanation for their degassing model.

Acknowledgments. The second author (JAS) gratefully acknowledges GSJ for support as a visiting scholar during 1996. The fourth author $(\mathrm{FG})$ was funded by a LDRD grant (Magmatic Tritium) from Los Alamos National Laboratory. We thank Dr. N. Imai for providing us GSJ reference samples of JB1a and JR1. We thank Drs. S. Togashi and K. Uto for their helpful comments. This manuscript was greatly improved with critical and constructive comments from Drs. R. M. Conrey, M. A. Clynne, Cees-Jan de Hoog and J. W. Hedenquist.

\section{References}

Bacon, C. R., Magmatic inclusions in silicic and intermediate volcanic rocks, J. Geophys. Res., 91, 6091-6112, 1986.

Bacon, C. R. and J. Metz, Magmatic inclusions in rhyolites, contaminated basalts, and compositional zonation beneath the Coso volcanic field, California, Contrib. Mineral. Petrol., 85, 346-365, 1984.

Blake, S. and G. N. Ivey, Magma-mixing and the dynamics of withdrawal from stratified reservoirs, J. Volcanol. Geotherm. Res., 27, 153-178, 1986.

Chakraborty, S., J. R. Farver, R. A. Yund, and D. C. Rubie, Mg tracer diffusion in synthetic forsterite and San Carlos Olivine as a function of P, T and fO2, Phys. Chem. Minerals, 21, 489-500, 1994.

Clynne, M. A., A complex magma mixing origin for rocks erupted in 1915, Lassen Peak, California, J. Petrol., 40, 105-132, 1999.

Eichelberger, J. C., Origin of andesite and dacite: Evidence of mixing at Glass Mountain in California and at other circum-Pacific volcanoes, Geol. Soc. Amer. Bull., 86, 1381-1391, 1975.

Eichelberger, J. C., Vesiculation of mafic magma during replenishment of silicic magma reservoirs, Nature, 288, 446-450, 1980.

Feeley, T. C. and M. A. Dungan, Compositional and dynamic controls on mafic-silicic magma interactions at continental arc volcanoes: evidence from Cordon El Guadal, Tatara-San Pedro Complex, Chile, J. Petrol., 37, 1547-1577, 1996.

Gerlach, T. M., H. R. Westrich, and R. B. Symonds, Pre-eruption vapor in magma of the climatic Mount Pinatubo eruption: source of the giant stratospheric sulfur dioxide cloud, in Fire and Mud: Eruptions and Lahars of Mount Pinatubo, Philippines, edited by C. G. Newhall and R. S. Punongbayan, pp. 415-433, Univ. Washington Press, 1996.

Goff, F. and G. M. McMurtry, Tritium and stable isotopes of magmatic waters, J. Volcanol. Geotherm. Res., 97, 347-396, 2000.

Goff, F., G. M. McMurtry, J. A. Stimac, and A. I. Adams, Stable isotopes and tritium of magmatic water at Satsuma-Iwojima volcano, Japan, EOS trans, American Geophys. Union. 1994 Fall meeting.

Hattori, K., High-sulfur magma, a product of fluid discharge from underlying mafic magma: Evidence from Mount Pinatubo, Philippines, Geology, 21, 1083-1086, 1993.

Hedenquist, J. W., M. Aoki, and H. Shinohara, Flux of volatiles and ore- 
forming metals from the magmatic-hydrothermal system of SatsumaIwojima volcano, Geology, 22, 585-588, 1994.

Heiken, G. and J. C. Eichelberger, Eruptions at Chaos Crags, Lassen Volcanic National Park, California, J. Volcanol. Geotherm. Res., 7, 443-481, 1980.

Imai, N., S. Terashima, S. Itoh, and A. Ando, 1994 complication values for GSJ reference samples, "Igneous rock series", Geochem. J., 29, 91-95, 1995.

Jarosewich, E., J. A. Nelen, and J. A. Norberg, Reference samples for electron microprobe analysis, Geostandards Newsletter, 4, 43-47, 1980.

Jarosewich, E., R. Gooley, and J. Husler, Chromium augite-A new microprobe reference sample, Geostandards Newsletter, 11, 197-198, 1987.

Kamada, M., Volcanoes and geothermy of Satsuma-Iwojima, Kagoshima prefecture, J. Japan Geothermal Energy Assoc., 3, 1-23, 1964 (in Japanese).

Kawanabe, Y. and G. Saito, Volcanic activity of the Satsuma-Iwojima area during the past 6500 years, Earth Planets Space, 54, this issue, 295-301, 2002.

Kazahaya, K., H. Shinohara, and G. Saito, Degassing process of SatsumaIwojima volcano, Japan: Supply of volatile components from a deep magma chamber, Earth Planets Space, 54, this issue, 327-335, 2002.

Kitagawa, H., H. Fukuzawa, T. Nakamura, M. Okamura, K. Takemura, A. Hayashida, and Y. Yasuda, AMS ${ }^{14} \mathrm{C}$ dating of varved sediments from Lake Suigetsu, central Japan and atmospheric ${ }^{14} \mathrm{C}$ change during the late Pleistocene, Radiocarbon, 37, 371-378, 1995.

Kouchi, A. and I. Sunagawa, A model for mixing basaltic and dacitic magmas as deduced from experimental data, Contrib. Mineral. Petrol., 89, 17-23, 1985

Kouchi, A., A. Tsuchiyama, and I. Sunagawa, Effect of stirring on crystallization kinetics of basalt: texture and element partitioning, Contrib. Mineral. Petrol., 93, 429-438, 1986.

Koyaguchi, T., Evidences for two-stage mixing in magmatic inclusions and rhyolitic lava comes in Niijima island, Japan, J. Volcanol. Geotherm. Res., 29, 71-98, 1986a.

Koyaguchi, T., Textural and compositional evidence for magma mixing and its mechanism, Abu volcano group, Southwestern Japan, Contrib. Mineral. Petrol., 93, 33-45, 1986b.

Larocque, A. C. L., J. A. Stimac, J. D. Keith, and M. A. E. Huminicki, Evidence for open-system behavior in immiscible Fe-S-O liquids in silicate magmas: Implications for contributions of metals and sulfur to ore-forming fluids, Canadian Mineralogist, 38, 1233-1249, 2000.

Lindsley, D, H., Pyroxene thermometry, Amer. Mineral., 68, 477-493, 1983

Linneman, S. R. and J. D. Myers, Magmatic inclusions in the Holocene rhyolites of Newberry volcano, central Oregon, J. Geophys. Res., 95(B11) 17677-17691, 1990.

Machida, H. and F. Arai, Akahoya ash-a Holocene widespread tephra erupted from the Kikai caldera, south Kyushu, Japan, The Quaternary Res., 17, 143-163, 1978 (in Japanese with English abstract).

Notsu, K., K. Ono, and T. Soya, Strontium isotopic relations of bimodal volcanic rocks at Kikai volcano in the Ryukyu arc, Japan, Geology, 15, 345-348, 1987.

Ono, K., Long-term forecast of volcanic eruptions, Bull. Volcanol. Soc. Japan., 34, S201-S214, 1990 (in Japanese).

Ono, K., T. Soya, and T. Hosono, Geology of Satsuma-Io-jima district. Quadrangle Series, Scale 1:50,000, Geol. Surv. Japan, 80 p., 1982 (in Japanese with English abstract).

Pallister, J. S., R. P. Hoblitt, G. P. Meeker, R. J. Knight, and D. F. Siems, Magma mixing at Mount Pinatubo: Petrographic and chemical evidence from the 1991 deposits, in Fire and Mud: Eruptions and Lahars of Mount Pinatubo, Philippines, edited by C. G. Newhall and R. S. Punongbayan, pp. 687-731, Univ. Washington Press, 1996.

Persikov, E. S., The viscosity of magmatic liquids: experiment, generalized patterns, a model for calculation, applications, in Physical Chemistry of Magmas, edited by L. L. Perchuk and I. Kushiro, pp. 1-40, SpringerVerlag, 1990.

Saito, G., K. Kazahaya, H. Shinohara, J. A. Stimac, and Y. Kawanabe, Variation of volatile concentration in a magma system of Satsuma-Iwojima volcano deduced from melt inclusion analyses, J. Volcanol. Geotherm. Res., 108, 11-31, 2001

Sakuyama, M., Evidence of magma mixing: Petrological study of Shirouma-Oike calc-alkaline andesite volcano, Japan, J. Volcanol. Geotherm. Res., 5, 179-208, 1979.

Shaw, H. R., Links between magma-tectonic rate balances, plutonism and volcanism, J. Geophys. Res., 90, 11275-11288, 1985.

Shinohara, H., W. F. Giggenbach, K. Kazahaya, and J. W. Hedenquist, Geochemistry of volcanic gases and hot springs of Satsuma-Iwojima, Japan: Following Matsuo, Geochem. J., 27, 271-285, 1993.

Shinohara, H., K. Kazahaya, G. Saito, N. Matsushima, and Y. Kawanabe, Degassing activity from Iwodake rhyolitic cone, SatsumaIwojima volcano, Japan: Formation of a new degassing vent, 1990-1999, Earth Planets Space, 54, this issue, 175-185, 2002.

Sparks, R. S. J. and L. A. Marshall, Thermal and mechanical constraints on mixing between mafic and silicic magmas, J. Volcanol. Geotherm. Res., 29, 99-124, 1986.

Stimac, J. A. and T. H. Pearce, Textural evidence of mafic-felsic magma interaction in dacite lavas, Clear Lake, California, Amer. Mineral., 77, 795-809, 1992.

Stimac, J. A., T. H. Pearce, J. M. Donnelly-Nolan, and B. Carter Hearn, Jr., The origin and implications of undercooled andesitic inclusions in rhyolites, Clear Lake Volcanoes, California, J. Geophys. Res., 95, 1772917746, 1990.

Takamiya, H. and S. Nishimura, Thermoluminescence ages of some volcaniclastic materials, Nucl. Tracks Radiat. Meas., 11, 251-257, 1986.

Tepley III, F. J., J. P. Davidson, and M. A. Clynne, Magmatic interactions as recorded in plagioclase phenocrysts of Chaos Crags, Lassen Volcanic Center, California, J. Petrol., 40, 787-806, 1999.

Thomas, N., S. Tait, and T. Koyaguchi, Mixing of stratified liquids by the motion of gas bubbles: application to magma mixing, Earth Planet. Sci. Lett., 115, 161-175, 1993.

Togashi, S. and S. Terashima, The behavior of gold in unaltered island arc tholeiitic rocks from Izu-Oshima, Fuji, and Osoreyama volcanic areas, Japan, Geochim. Cosmochim. Acta, 61, 543-554, 1997.

Tomiya, A. and E. Takahashi, Reconstruction of an evolving magma chamber beneath Usu volcano since the 1663 eruption, J. Petrol., 36, 617-636, 1995.

Tsuchiyama, A., Crystallization kinetics in the system $\mathrm{CaMgSi}_{2} \mathrm{O}_{6}$ $\mathrm{CaAl}_{2} \mathrm{Si}_{2} \mathrm{O}_{8}$ : development of zoning and kinetics effects on element partitioning, Amer. Mineral., 70, 474-486, 1985a.

Tsuchiyama, A., Dissolution kinetics of plagioclase in the melt of the system diopside-albite-anorthite, and origin of dusty plagioclase in andesites, Contrib. Mineral. Petrol., 89, 1-16, 1985 b.

Ueda, A. and T. Itaya, Microphenocrystic pyrrhotite from dacite rocks of Satsuma-Iwojima, Southwest Kyushu, Japan and the solubility of sulfur in dacite magma, Contrib. Mineral. Petrol., 78, 21-26, 1981.

Ujike, O., T. Soya, and K. Ono, Major-element, Rb, Sr, Y and Zr composition and origin of volcanic rocks from the Kikai Caldera, south of Kyushu. J. Japan. Assoc. Mineral. Petrol. Econ. Geol., 81, 105-115, 1986 (in Japanese with English abstract).

Wallace, P. J. and T. M. Gerlach, Magmatic vapor source for sulfur dioxide released during volcanic eruptions: Evidence from Mount Pinatubo, Science, 265, 497-499, 1994.

G. Saito (e-mail: saito-g@aist.go.jp), J. A. Stimac, Y. Kawanabe, and F. Goff 